\title{
Making Time and Space for Art: An Examination of an Artist-in-Residence within a Postsecondary Art Education Program
}

\author{
Alison Lea Shields, University of Victoria \\ alisonleashields@gmail.com \\ Ingrid Mary Percy, Memorial University \\ ingridmpercy@gmail.com
}

\author{
Teresa Vander Meer-Chassé, White River First Nation \\ tsvc@live.ca
}

\begin{abstract}
This article examines the process and impact of an artist-in-residence program in Art Education at the University of Victoria. After an open call to artists, contemporary Upper Tanana visual artist, Teresa Vander Meer-Chassé, member of the White River First Nation of Beaver Creek, Yukon and Alaska was selected as the inaugural artist-in-residence. Through researchcreation and qualitative methods this research examines the artist's artistic process and the impact of an artist-in-residence on students' and faculty's perception of artistic practice and their experience working with an artist-in-residence within a post-secondary space of learning. Through photographic documentation, reflections and interviews by participants, the article examines ways the artist-in-residence enriched student and faculty learning in a Faculty of Education.
\end{abstract}

Keywords: Artist-in-residence; post-secondary education; artistic inquiry; Indigenous pedagogy; beading

\section{Introduction}

7 his article examines the artistic research conducted and the impact on students of an artistin-residence program in Art Education within the Department of Curriculum and Instruction in the Faculty of Education at the University of Victoria. The intention of this research was to examine the process of artistic research as it relates to pedagogy as well as the impact of artistic research within a space of learning (the Faculty of Education). We include an Art Education Professor, a doctoral student/Fine Arts Professor and an Artist-in-Residence. In this article, we discuss our approach to working with the artist-in-residence, address the qualitative and artistic research methods used, and the findings of the research. The findings are presented through photographic documentation, observations of the artistic process, reflection by the artistin-residence, and interviews with faculty and students. The artist-in-residence was a collaborative project between the researchers, the artist, the faculty, and students who visited the gallery. For this reason, this article brings together these diverse voices to highlight the collaborative artistic and pedagogical potentials of an artist-in-residence.

After an open call to artists, contemporary Upper Tanana visual artist Teresa Vander MeerChassé, proud member of the White River First Nation of Beaver Creek, Yukon, and Alaska was 
selected as the inaugural artist-in-residence. She inhabited the Wilfrid Johns Gallery for one month in November, 2019. During this time, the gallery functioned simultaneously as exhibition space, educational space, studio space, and research space. Faculty, students, and community members were invited to visit the gallery, make art and discuss pedagogy with the artist. In examining the artist-in-residence program, this research asks: What is the impact on students' and faculty's perceptions of artistic practice and what is their experience working with the artist in this space?

\section{Background}

The Wilfrid Johns Gallery was created by Professor Wilfrid Johns who was the first Chair of Art Education at the University of Victoria in 1963 to display student work from within the Art Education courses as well as children's art. The gallery is centrally located in the space between the art education studio classes and is visible and accessible to all students and faculty working within MacLaurin.

The gallery has played a significant role throughout the years in Art Education at the University of Victoria. Through this project we sought to draw from the traditions of the gallery, while expanding its purpose to address significant changes to the BC School Curriculum, and to draw from inquiry-based and experiential approaches to learning. Through inviting an artist to work in the gallery, we focus on the process-based approaches of the curriculum. The British Columbia Elementary and Secondary Curriculum is structured around core competencies: creative thinking; critical thinking; communication; personal and cultural identity; personal awareness and responsibility; and social responsibility (https://curriculum.gov.bc.ca). Drawing from the researcher's belief in art's capacities to develop these competencies, the new Art Education curriculum focuses on artistic inquiry processes as students develop critical and creative thinking while learning about themselves and the world they inhabit through art making. In addition, these recent changes to the British Columbia Curriculum (2014-2016) integrate First People's Principles of Learning across all subjects. The University of Victoria acknowledges the lək ${ }^{\mathrm{w}}$ əyən peoples on whose territory the university stands and the Songhees, Esquimalt and WSÁNEĆ peoples whose historical relationships with the land continue to this day (https://www.uvic.ca). As it relates to the selection of the artist-in-residence, the researchers considered not only the valuable Indigenous perspectives brought to the faculty through the artist-in-residence, but also the significance of providing spaces for Indigenous voices to have presence within academic institutions.

\section{Literature Review}

Artists-in-residences are common practice within educational settings, arts institutions, and community. The working definition of an artist-in-residence that we use is open-ended, referring simply to an artist residing temporarily in a particular space for the purpose of artistic creation. Similarly, the role of the artist-in-residence as they engage with the community differs for each context. While not attempting to oversimplify the uniqueness of each residency that is defined by each artist's methodology, through research into artists-in-residence within educational settings, we found two distinct approaches or roles of artists. In the first approach, often seen within fine arts departments, the artist develops their own art work within a studio or gallery in an educational institution. At the post-secondary level, artists-in-residence are common within departments of fine or visual arts or in other university departments. While new artists-in-residences are constantly being introduced, some examples of Canadian universities that have ongoing artists-in-residence are Queens University, Mount Allison University, Emily Carr University of Art and Design, University of Victoria and Quest University. In these cases, the artist-in-residence may work 
alongside faculty and students on a body of work, and extend student learning by providing opportunities to observe an artistic practice and engage with a professional artist. While I believe it is commonly accepted within arts communities that artists-in-residence are positive experiences for both the artist and the community, little research has examined the impact of these residencies.

In the second approach, the artist draws from their expertise and experience as an artist to teach or guide students toward specific learning objectives. In this case, the outcome is focused on the learning of the students. Far more research has addressed this approach, particularly in K-12 contexts (e.g., Adams, 2005; Ash, 2016; Hunter-Doniger, 2015; Hunter-Doniger \& Berlinsky, 2017; Lachapelle, 2016; LeBlanc \& Irwin, 2019; Winderlich, 2016; Woywod \& Deal, 2016). Stephanie Springgay leads a SSHRC funded project entitled Pedagogical Impulse that examines the impact of social practice artists-in-residences within Toronto-based schools and demonstrates how artists-in-residence offer a creative collaboration between artists, researchers, teachers and students (Miles \& Springgay, 2019; Rotas \& Springgay, 2014; Springgay \& Truman, 2016). Within British Columbia, Art Starts in Schools (https://artstarts.com) is an example of an organization that facilitates artists working within public schools through artists-in-residence. In this case, the artist works with the classroom teacher to develop a residency that addresses outcomes in the British Columbia Curriculum, often focused on arts integration.

Less research has focused on artists-in-residence in universities, but those that have employed the second approach, wherein the artist takes on the role of teacher and the focus is on the learning outcomes of students. For example, Ungemah and Stokas (2017) explored how artistsin-residence leading mandatory post-secondary arts courses in education enhanced student learning. LeBlanc \& Irwin (2019) studied how artists-in-residence across arts education (i.e. music, drama, visual and language arts) created a space for exploring contemporary national identity. The McGill Art Hive (https://www.mcgill.ca/arthive/) initiative, demonstrates how an art educational studio space may promote collaborations between faculty and students in a Faculty of Education (Bonneau, 2019).

The intention of this residency was to draw from the approaches above to develop the residency within the Wilfrid Johns gallery. The intention was to have the artist's practice within the space be a prompt for pedagogical action. The residency, therefore, draws from the artist's research methodology to provide a pedagogical experience for the students, faculty, and community. The artist would develop their own art practice within the gallery, while working with faculty, students and researchers to provide learning opportunities. The goal was to examine how the artist-in-residence might deepen, extend or compliment students' academic experience, without having pre-prescribed learning outcomes for students. We believe this emergent process is essential to the project as it recognizes the particular, situated and emergent quality of art making and learning. Further it allows for each individual involved to have their own unique learning experience rather than having their learning outcomes pre-decided. It is our contention that within a university system heavily weighted on prescribed and measurable objectives that this residency may provide learning experiences beyond those already received.

\section{Theoretical Orientation}

We draw from the theoretical lens of the work of Barbara Bolt $(2004 ; 2007 ; 2013 ; 2016)$ and Estelle Barrett $(2007 ; 2013)$ who examine artistic approaches to research as performative. Bolt (2016) argues that a performative paradigm recognizes that artistic research is ontologically performative in its capacity to provoke and generate experiences. A performative lens of artistic practice emphasizes engagement with artistic research as an embodied, affective, sensory, 
experiential, and emergent learning process. A performative view of art recognizes that making art or viewing art is a generative process that has particular effects on each person within a particular time and place. This performative way of learning does not view art-making as simply the creation of a pre-determined final product, but instead as an ongoing prompt to learning, thinking, and meaning-making. It is through this lens that we view the residency as similarly multiple and indeterminant (Barrett, 2013) through its capacity to prompt learning, thinking and making through interaction with the art and artist.

Through the lens of performativity, we examine an artist-in-residence for its potential as an emergent event (Richardson \& Walker (2011). Richardson and Walker (2011) address emergence and art-making as a process of becoming, wherein art, ideas, understandings and relationships emerge throughout the process. Through setting the conditions for pedagogical encounters, we asked what learning opportunities might emerge for students, faculty and the artistin-residence. Drawing from a performative lens of artistic processes, the residency proposes that an artist-in-residence is similarly a process-event that occurs in a particular time and space through ongoing dialogue with participants.

The research was set at a university that is committed to working with Indigenous peoples as they work toward decolonization and indigenization. Many researchers have examined ways of weaving Indigenous knowledges and worldviews into postsecondary institutions (Bartlett, Marshall \& Marshall, 2012; Battiste \& Youngblood Henderson, 2009; Pidgeon, 2014; Ragoonaden, 2017) while also confronting the Eurocentric and colonial structures within a university (Battiste et al., 2002) and addressing approaches to decolonization in the university (Mitchell, Thomas \& Smith, 2018). Gaudry and Lorenz (2018) highlight three approaches to Indigenization as inclusion, reconciliation and decolonization and conclude that most postsecondary institutions in Canada focus predominantly on Indigenous inclusion. Within the University of Victoria Faculty of Education, Tanaka et al. (2007) examined how a course based on Indigenous pedagogy for pre-service teachers shaped their views of teaching and learning. Indigenous pedagogies became embedded within our research project because of the artist selected. Further, Indigenous Education Faculty, interviewed for this research, brought their experience and insights into the analysis of the impact of the project.

\section{Methodology}

The research combined both research-creation and qualitative research methods to examine both the process and impact of the residency. The research-creation methods were performed by the artist herself within the gallery as she made art within the gallery throughout the month while engaging with visitors in art-making and dialogue. We employed research-creation drawing from the works of Bolt \& Barrett (2007, 2013), Loveless (2019) and Springgay \& Truman (2016). Through these approaches, we focus on processes and invite students and faculty to become witnesses and participants to the process. While the research-creation methods created the conditions and content for how the research unfolded, the processes of the research-creation and the impact on students were examined through qualitative methods. The impact on students was examined through analysis of student participation in artistic events, integration of the gallery within course content and student responses. Follow up interviews with the artist, students, and faculty were performed to examine the learning experiences for the artist, faculty and students and to examine experiences and observations from diverse perspectives. An active interview format (Gubrium \& Holstein, 2003) was used to prompt open-ended conversation and self-reflection about artistic practices (Hannula et al., 2014). We also integrated photo-documentation strategies 
and image-based research methodologies (Pink, 2012; Rose, 2010) into the processes of data collection. Through the analysis of the interviews, several themes emerged about the ways time and space are structured within education, formal and informal ways of learning, and the role of conversation in education.

\section{Project Development}

An open call was put out to artists and approximately 30 submissions were received. The artist selected was Teresa Vander Meer-Chassé, a contemporary Indigenous artist from the White River First Nation of Beaver Creek, Yukon. Teresa Vander Meer-Chassé inhabited the gallery space for one month, transforming the space into an active studio space where students, faculty and the local community were invited to bead with Teresa as they discussed Indigenous pedagogies. Teresa created a welcoming space that mimicked a domestic space to model the way she learned beading from her grandmother at the kitchen table. Teresa Vander Meer-Chassé was selected as the artist because of her proposal to use the residency to not only create beadwork, but to also address her own research-creation questions related to Indigenous pedagogies through ongoing creative dialogue with the students and faculty.

In her submission, Teresa stated that throughout the residency, she would explore the following questions: 1. Is level of education [post-secondary art training] segregating artists into silos: those with a degree in art and those that are self-taught?; 2. Is Indigenous pedagogy (in regards to art) seen as worthy within or outside of academia? Are Indigenous and western pedagogy cohesive?; 3. Do educated and self-taught artists think about art and their processes differently? (ie. Can they communicate with one another?). Regarding her intentions in her submission proposal, Teresa stated:

I will mimic a kitchen table with beadwork supplies and projects in all stages of completion to be actively worked on. Throughout the month, I will begin to add these artworks to the wall space, in an attempt to answer some of the questions I'm asking. Using my Grandma's watch and learn method, I will teach students and faculty how to bead. Beading is often associated with conversation and the ultimate way I'd like to communicate with the department, igniting creativity and meaningful thought as we take this journey together.

The artist was selected because of her artistic inquiry approach. Rather than coming into the residency with fixed objectives, the artist provided prompts for inquiry that would be developed throughout the residency within the space and with the department. Thus, the residency aligned with the performative approach to research, wherein conditions were created to see what would emerge through making and dialogue.

\section{Figure 1}

Teresa Vander Meer-Chassé in Wilfrid Johns Gallery, 2019. 


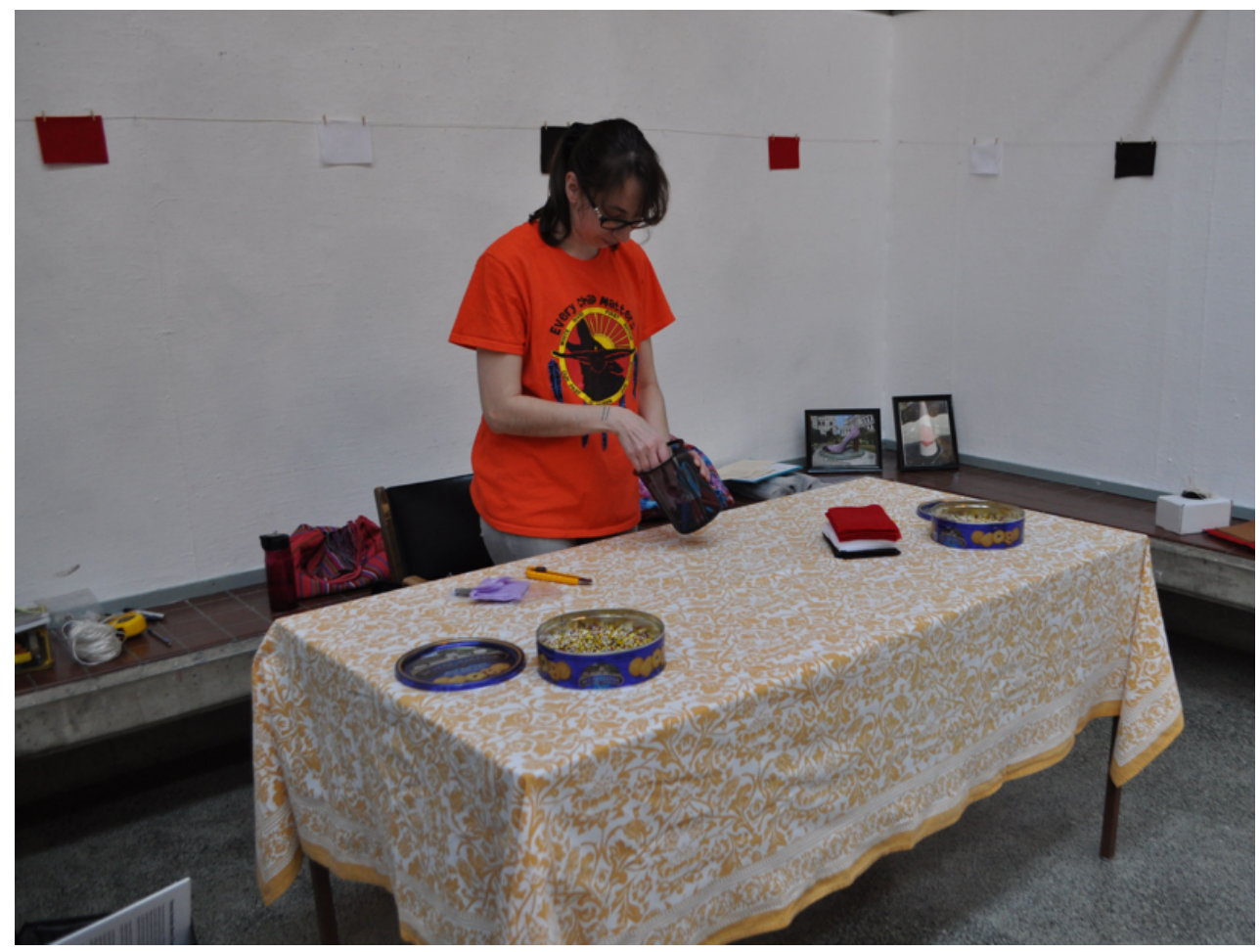

Notes. Photograph by Ingrid Percy.

\section{Figure 2}

Teresa Vander Meer-Chassé 's Installation in Wilfrid Johns Gallery, 2019.

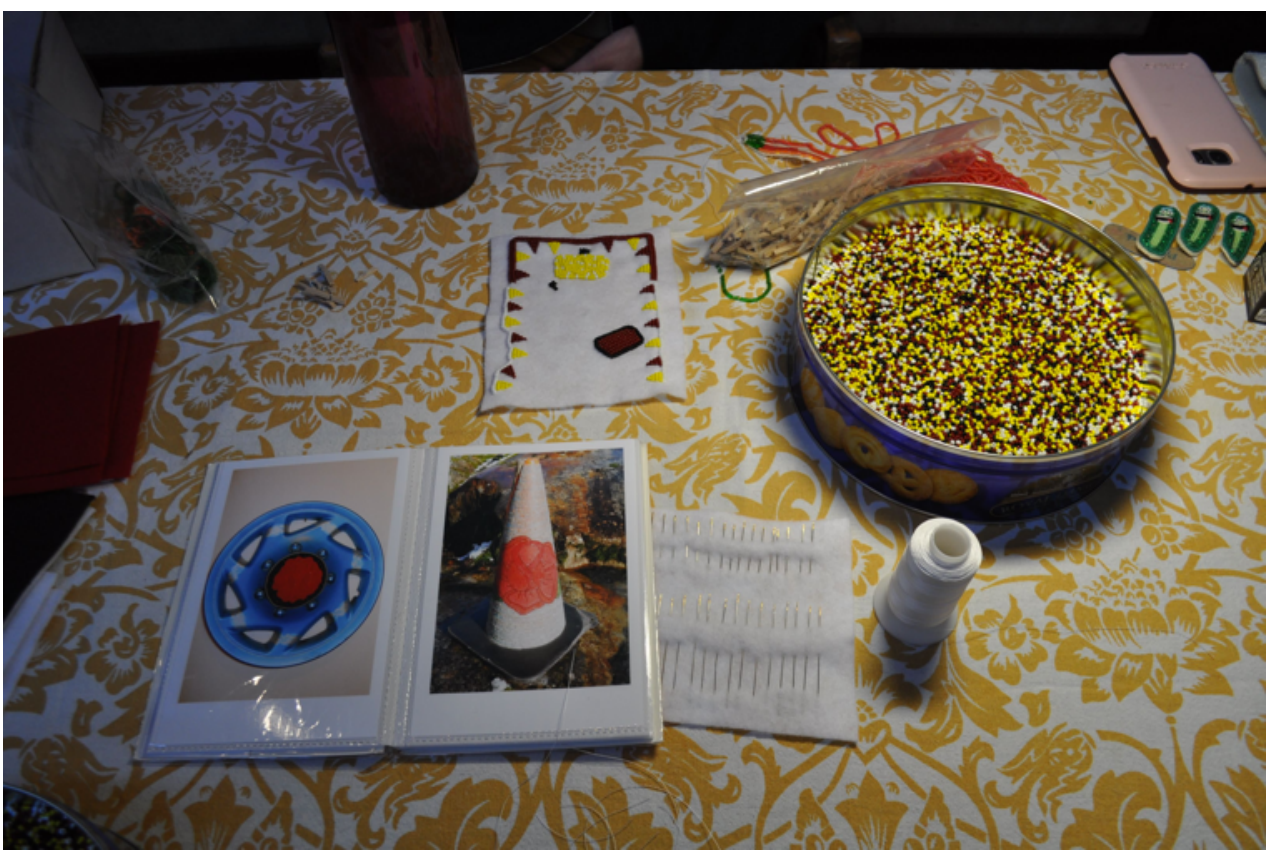

Notes: Photograph by Ingrid Percy. 


\section{Figure 3}

Teresa Vander Meer-Chassé's Installation in Wilfrid Johns Gallery, 2019.

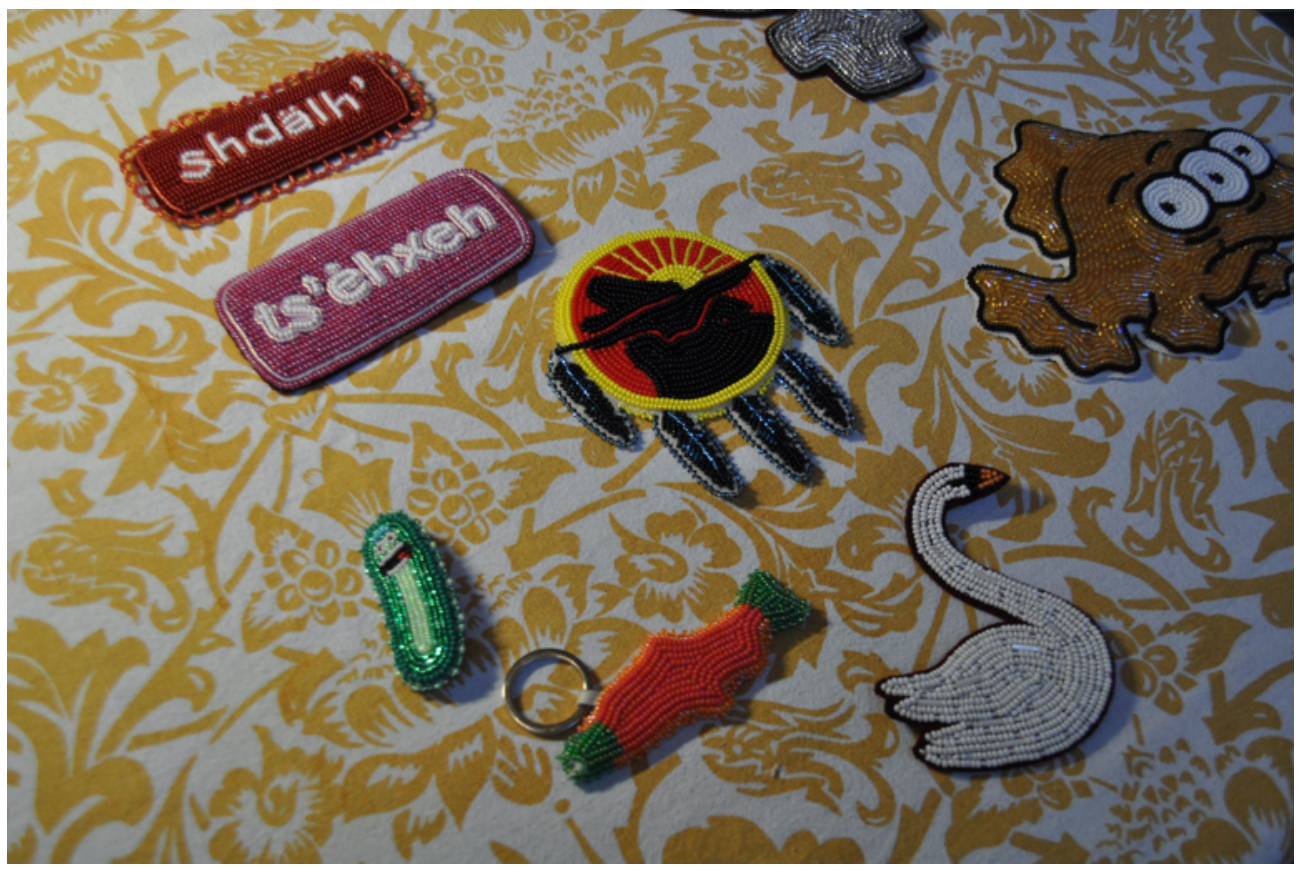

Notes: Photograph by Ingrid Percy.

\section{Discussion: The Emergent Installation}

Teresa Vander Meer-Chassé began the residency by setting up the gallery as a studio, exhibition space, kitchen, and pedagogical space. On one wall, she displayed family photographs of her grandparents. The installation simultaneously mimicked an exhibition while also alluding to family photographs hung in a home. Around the room hung bandanas which referenced potlaches. In the back of the gallery, Teresa set up a kitchen table with a table cloth, a tin of beads and some felt. The wall behind her had a string with clothes pins where she planned to hang works created by herself and visitors throughout the month. The back wall gradually became filled with felts with beadwork by faculty and students. Teresa engaged with small groups of visitors through teaching them the beading process, drawing from her watch-and-learn technique.

Along the other wall, Teresa installed a large paper displaying the research questions she had proposed that address Indigenous pedagogies and how artists learn (self-taught verses academically trained). Throughout the month, comments emerged on the wall in response to the questions. Some were added while visiting Teresa, while others were transcribed by Teresa in response to conversations with visitors. Others emerged to Teresa's surprise during times when she was not in the space. Many comments addressed ways that Indigenous pedagogies were at odds with the colonial structure of the university.

The artist engaged with the faculty and students in multiple ways. She invited full classes of students to come to the gallery. In these cases, the teaching occurred through artist-talk presentations and faculty/artist led discussions. She worked with smaller classes who engaged in dialogue while learning to bead. And she had intimate one-on-one conversations with faculty, students and community members who visited the space outside of class time for longer periods 
of time. The findings of this project, drawn from observation and follow-up interviews with faculty, students and community members revealed that the strength of an artist-in-residence within a Faculty of Education is not simply through re-enforcing prescribed learning outcomes, but rather in provoking discussions on ways of learning that may challenge or disrupt students' learning experience and/or daily routine. Thus, while some benefit was demonstrated in working with large classes that aligned with curricular content, larger impacts were felt from smaller groups or individual students who spent significant time with the artist. The artist-driven research questions confronted faculty and students to reconsider their understandings of pedagogy and learning. This finding became clear through conversations with students and faculty who discussed the importance of unstructured time within learning. Figures 4-11 show the installation and evolution of the exhibition throughout the month.

\section{Figure 4}

Teresa Vander Meer-Chassé's Installation in Wilfrid Johns Gallery, 2019.

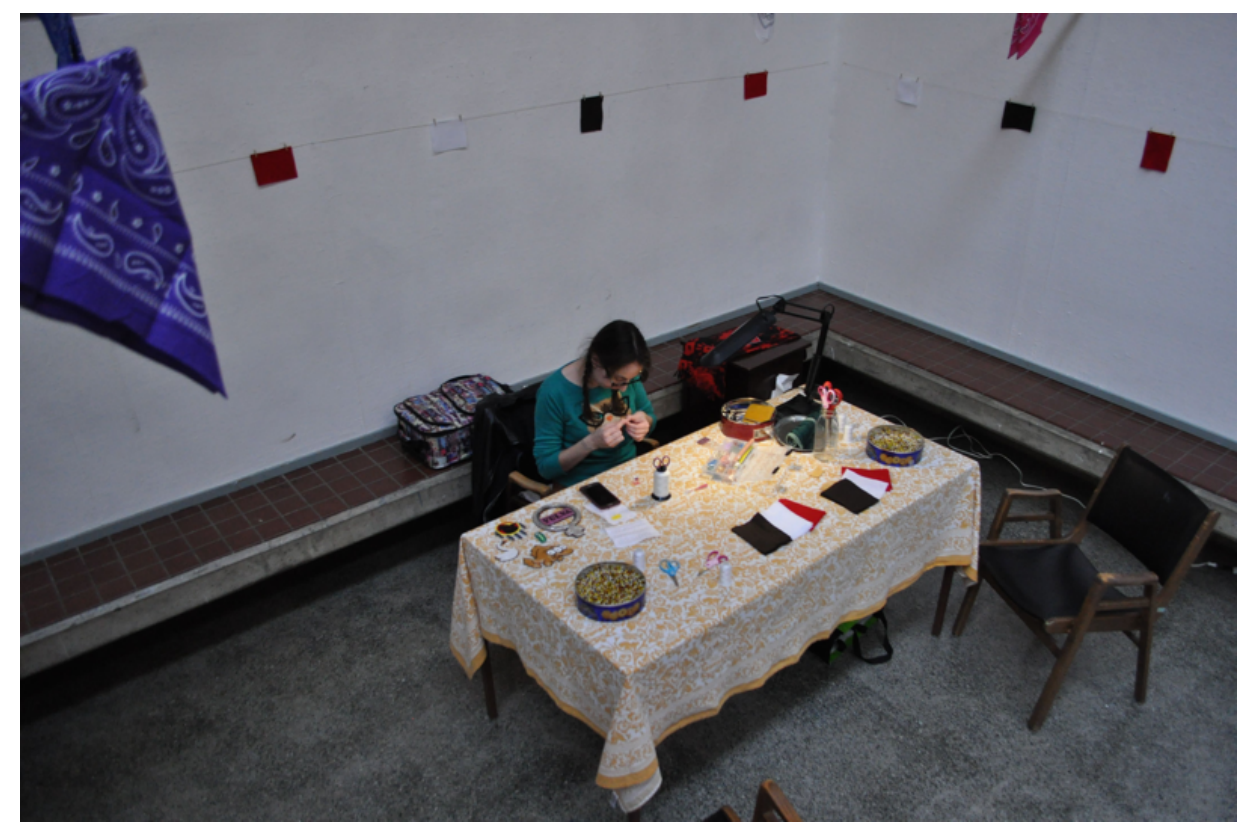

Notes: Photograph by Ingrid Percy.

Figure 5

Teresa Vander Meer-Chassé's Installation in Wilfrid Johns Gallery, 2019. 
Shields et al.

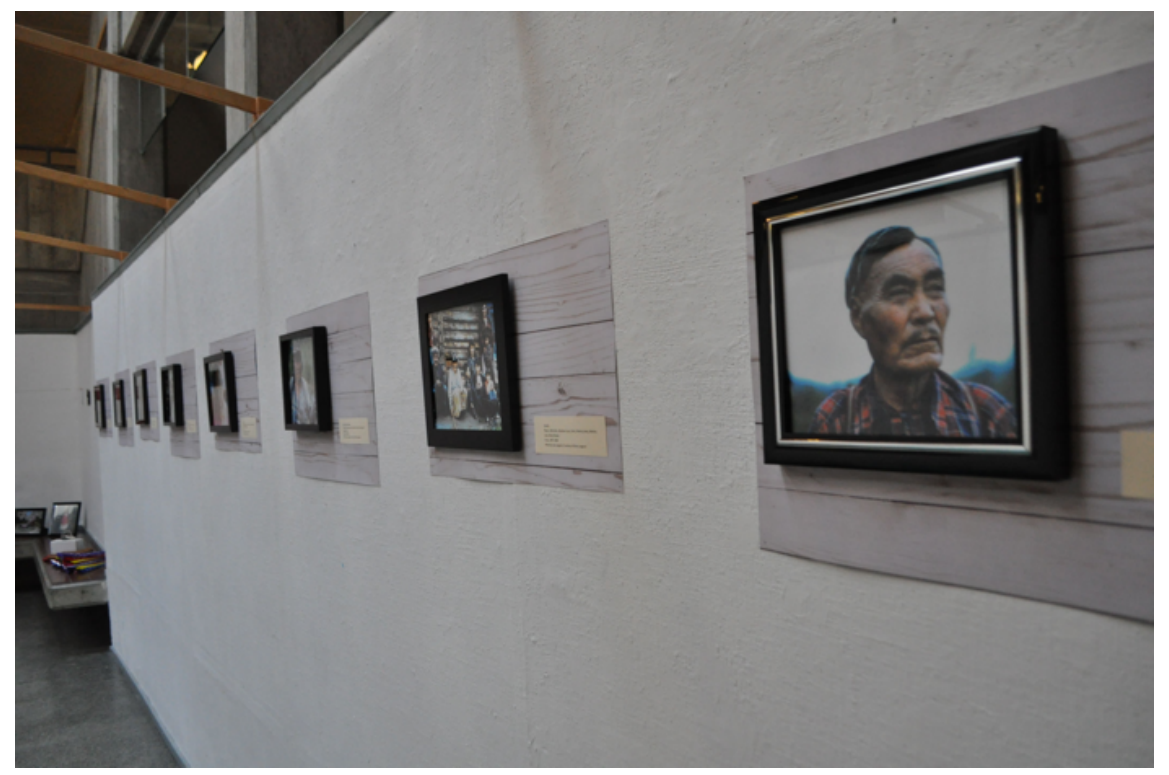

Notes: Photograph by Ingrid Percy.

\section{Figure 6}

Teresa Vander Meer-Chassé's Installation in Wilfrid Johns Gallery, 2019.

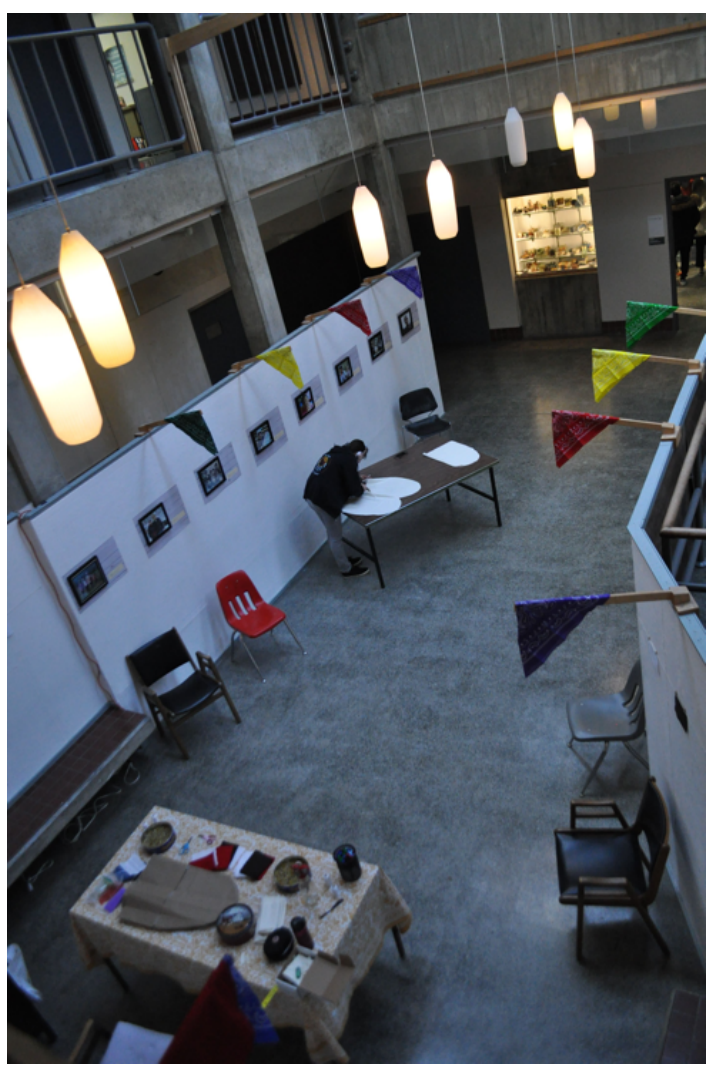

Notes: Photograph by Ingrid Percy.

Canadian Review of Art Education, 48(1) 


\section{Figure 7}

Teresa Vander Meer-Chassé's Installation in Wilfrid Johns Gallery, 2019.

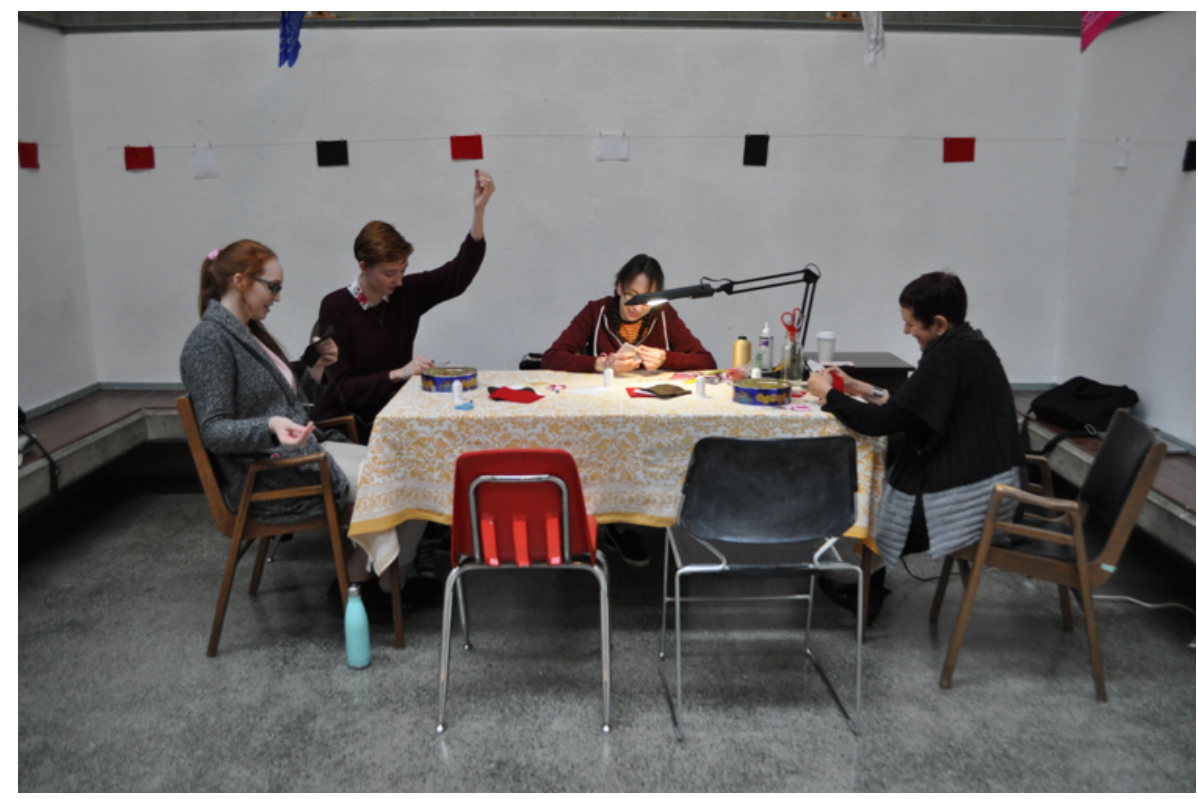

Notes: Photograph by Ingrid Percy.

\section{Figure 8}

Teresa Vander Meer-Chassé's Installation in Wilfrid Johns Gallery, 2019.

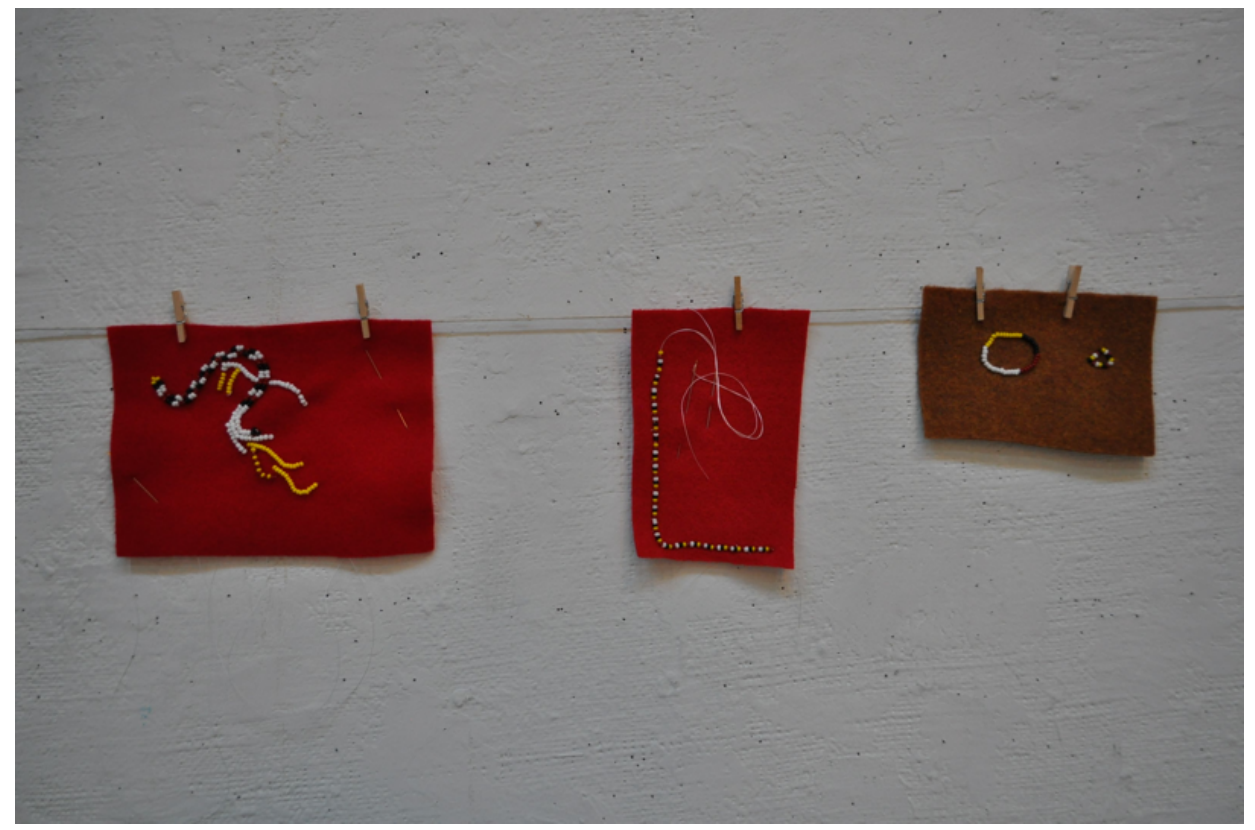

Notes: Photograph by Ingrid Percy. 


\section{Figure 9}

Teresa Vander Meer-Chassé’s Installation in Wilfrid Johns Gallery, 2019.

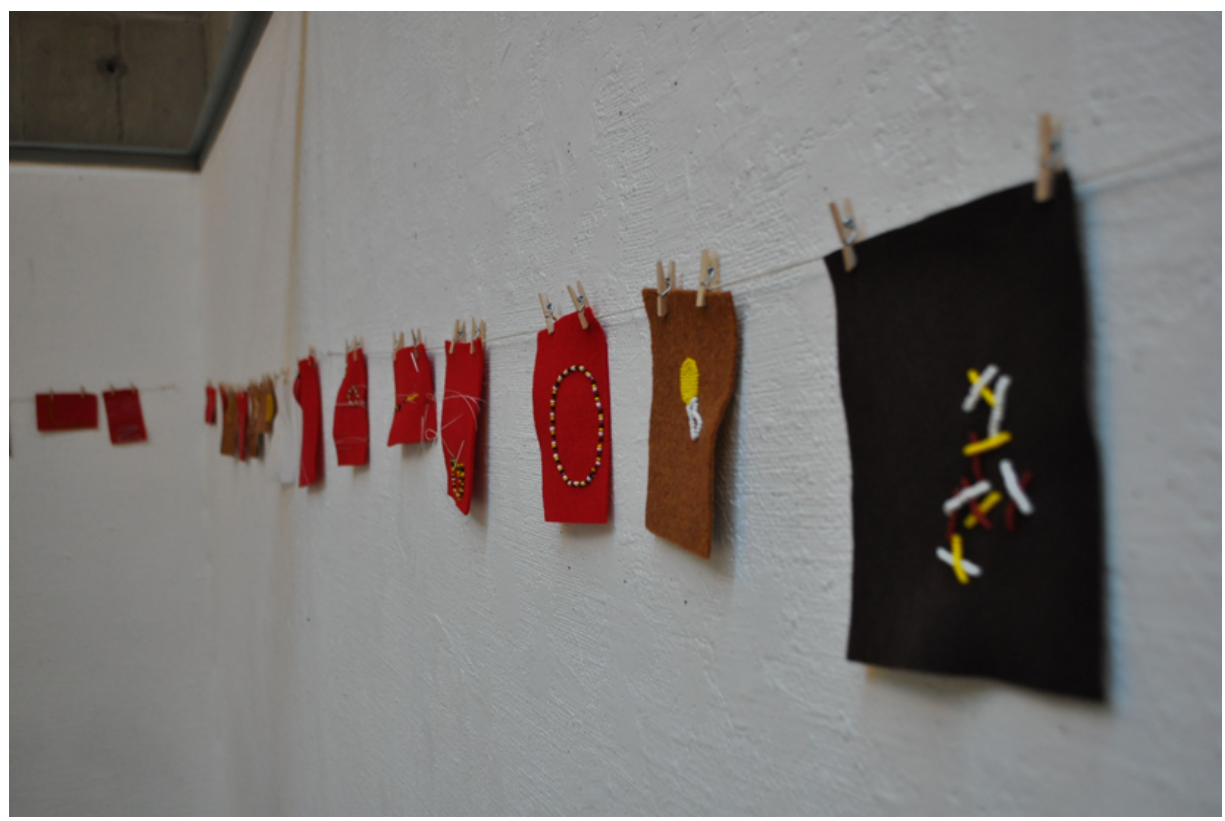

Notes: Photograph by Ingrid Percy.

\section{Figure 10}

Teresa Vander Meer-Chassé 's Installation in Wilfrid Johns Gallery, 2019.

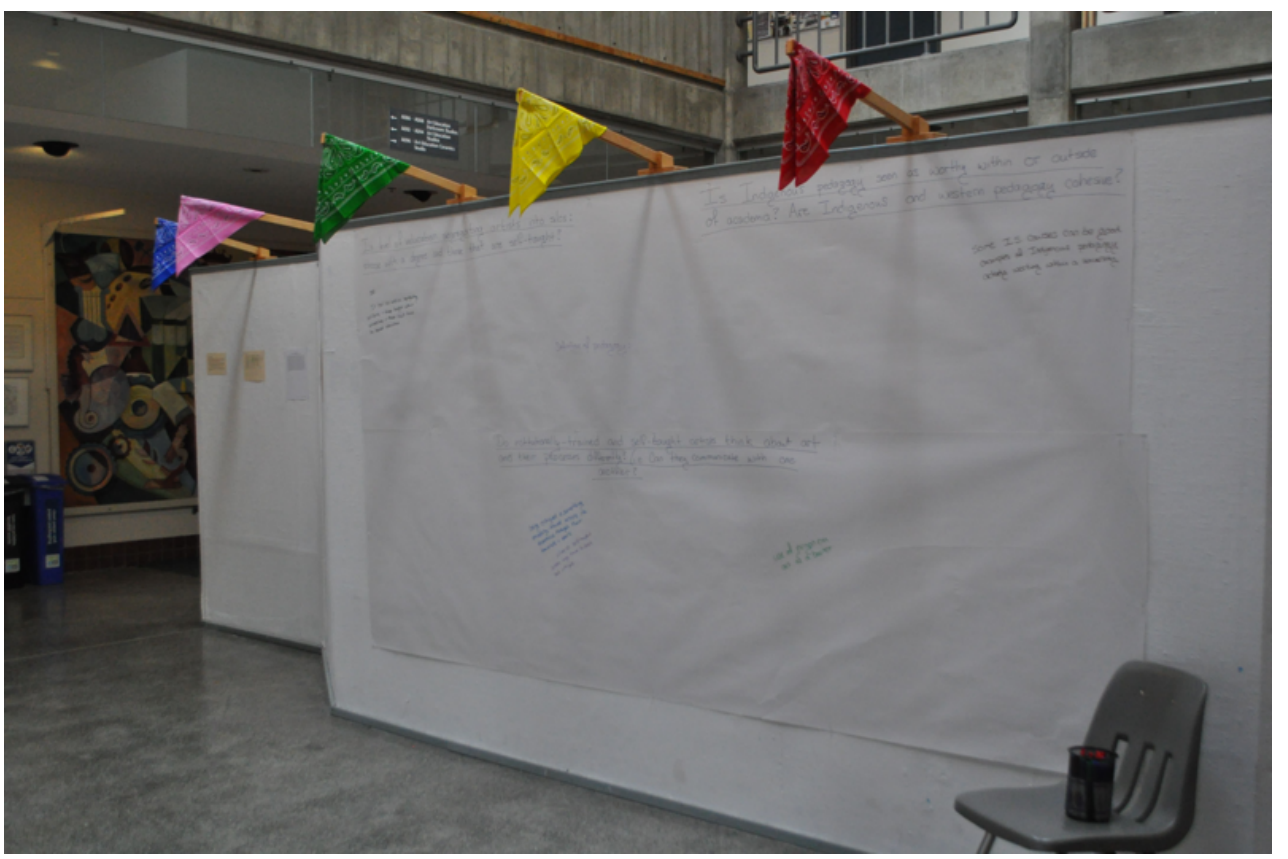


Notes: Photograph by Ingrid Percy.

\section{Figure 11}

Teresa Vander Meer-Chassé's Installation in Wilfrid Johns Gallery, 2019.

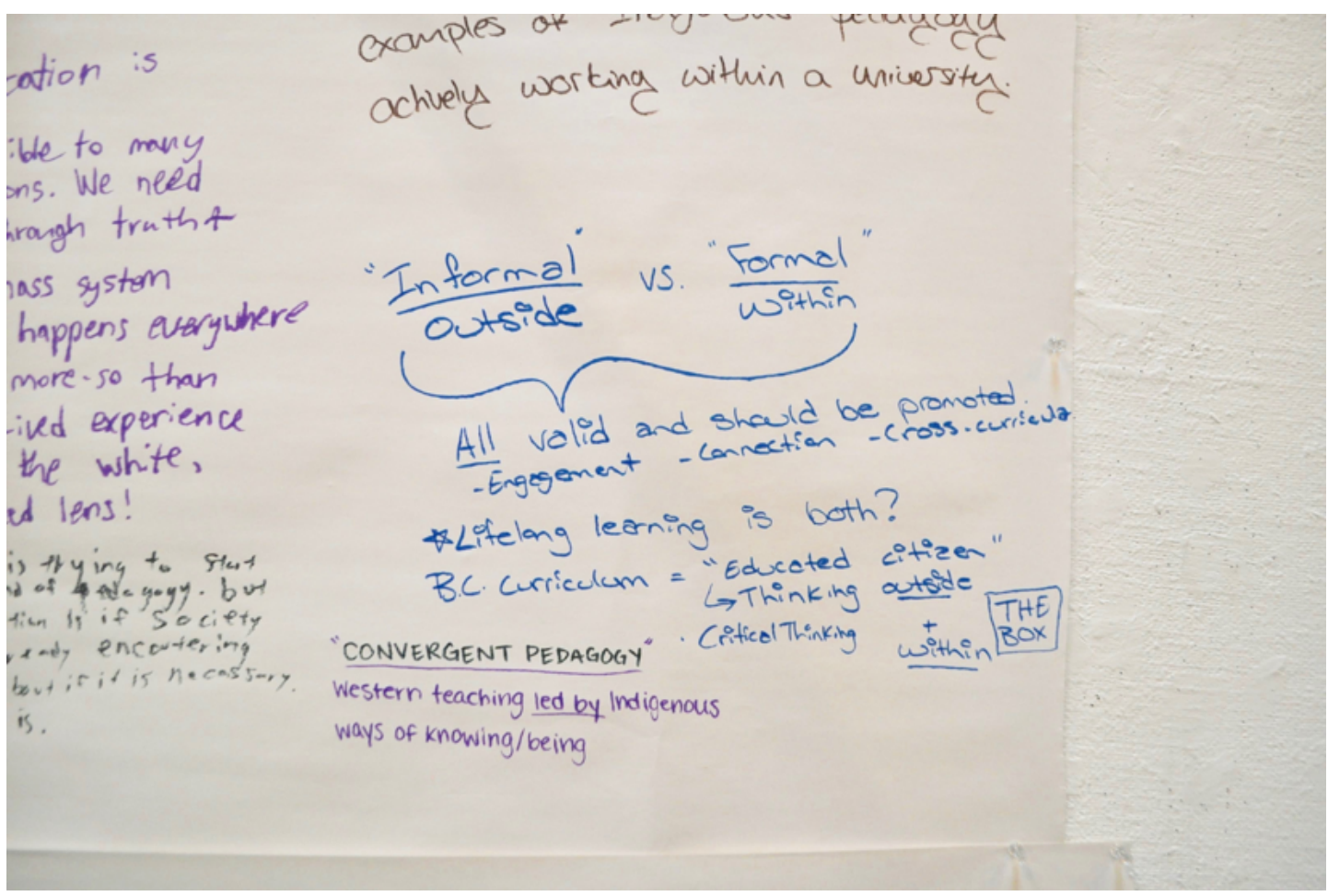

Notes: Photograph by Ingrid Percy.

\section{Findings}

The following themes emerged through participant observation and interviews that will be discussed in the findings: structured/unstructured time; formal and informal ways of learning; conversation; and spaces of learning. While in many cases the residency enriched and extended course outcomes, more importantly, through addressing these themes, the residency revealed what is not taught within structured coursework. Further, it revealed the unexpected conversations and encounters that may emerge through providing a space outside of the classroom for art making. Students and faculty addressed the challenges of finding time for art making and dialogue, while also expressing their desire for unstructured time for these moments. The realizations prompted some education students to consider how they may foster unstructured spaces of learning in their classrooms. Lastly, the artist prompted conversation about Indigenous pedagogies within academia. These themes will be addressed through an examination of the interviews with participants.

To acknowledge these different lenses and experiences of participants, the findings are presented to bring in the diverse voices of those involved. We begin by presenting how the residency emerged throughout the month, followed by a reflection by the artist (Teresa Vander Meer-Chassé). Next, we discuss three types of engagement with faculty and students (full class presentations/workshops, classroom inquiry and out-of-class visits) through interviews with 
faculty and students. Thirdly, Ingrid Percy reflects on her role in the residency. Lastly, findings related to the structuring of time and space are discussed in relation to Indigenous pedagogies. Figures 12-20 show the installation of the exhibition and Teresa's interaction with participants.

\section{Reflections from Artist (Teresa Vander Meer-Chassé): Kitchen Table as Informal Site of Learning}

Dineh k'èh Ddhälh kït Nelnah shoosi. Noodlee k'èh Teresa Vander Meer-Chassé shoosi. My Upper Tanana name is Teresa Vander Meer-Chassé and I am a member of the White River First Nation of Beaver Creek, Yukon. I had the great pleasure of being the inaugural Artist-in-Residence for the Art Education Department at the University of Victoria during the month of November 2019.

Being the first of anything is a privilege, an honour and comes with responsibility that can influence the future of a program. I was drawn to the program because it wasn't your typical artist residency where an artist is given a private space to create work in solitude. This particular residency asked for the artist to engage with students, faculty, and the public each day they are in residence.

I decided that the project I would focus on while in residence should revolve around public engagement. I developed a way in which students, faculty, and the public could come into the space, sit down, engage with me, and learn the first steps in beading. The space was made to resemble a home. I had photos of my family on the walls and a kitchen table at the far end where I sat and beaded. I had chairs on the opposite side of the table from me where I would invite guests to join me.

Once participants joined me at the table, I taught them the basic techniques of beading. I am conscious of cultural appropriation and to ensure we didn't cross that line; I informed each individual that I was only teaching them technique and not design. I began conversing with the participants and asked questions that pertained to academia and whether or not Indigenous pedagogy can play a role. I was prompted to ask this question and others that revolved around art and academia because of personal experience.

I received my BA from the University of Victoria in Cultural Anthropology but pursued my career in self-taught art. As I navigate current artistic waters, I've come to notice that academia trumps self-taught or community-based learning in many people's eyes. I come from family members that survived great hardships as children and have little to no positive experiences with school; from residential school abuses to surviving World War Two as a young child. My family is filled with self-made, self-taught, communitybased, family-oriented individuals that have become successful in whatever they pursue.

While Alison conducted her research, I was conducting my own. I learned that many people within the institution know that Indigenous pedagogy is needed but are unsure how to access it. I learned that, through beadwork, the way in which people learn is apparent and measurable. I learned that constraints over time can impede one's learning and that time can stand still when deep and meaningful conversations are struck. I learned that speaking openly to a complete stranger is possible through art making and creating. And finally, I learned a lot about myself, as an artist, and I will hold the stories the participants and I have shared with one another closely as we move forward. 


\section{Figure 12}

Teresa Vander Meer-Chassé beading in Wilfrid Johns Gallery, 2019

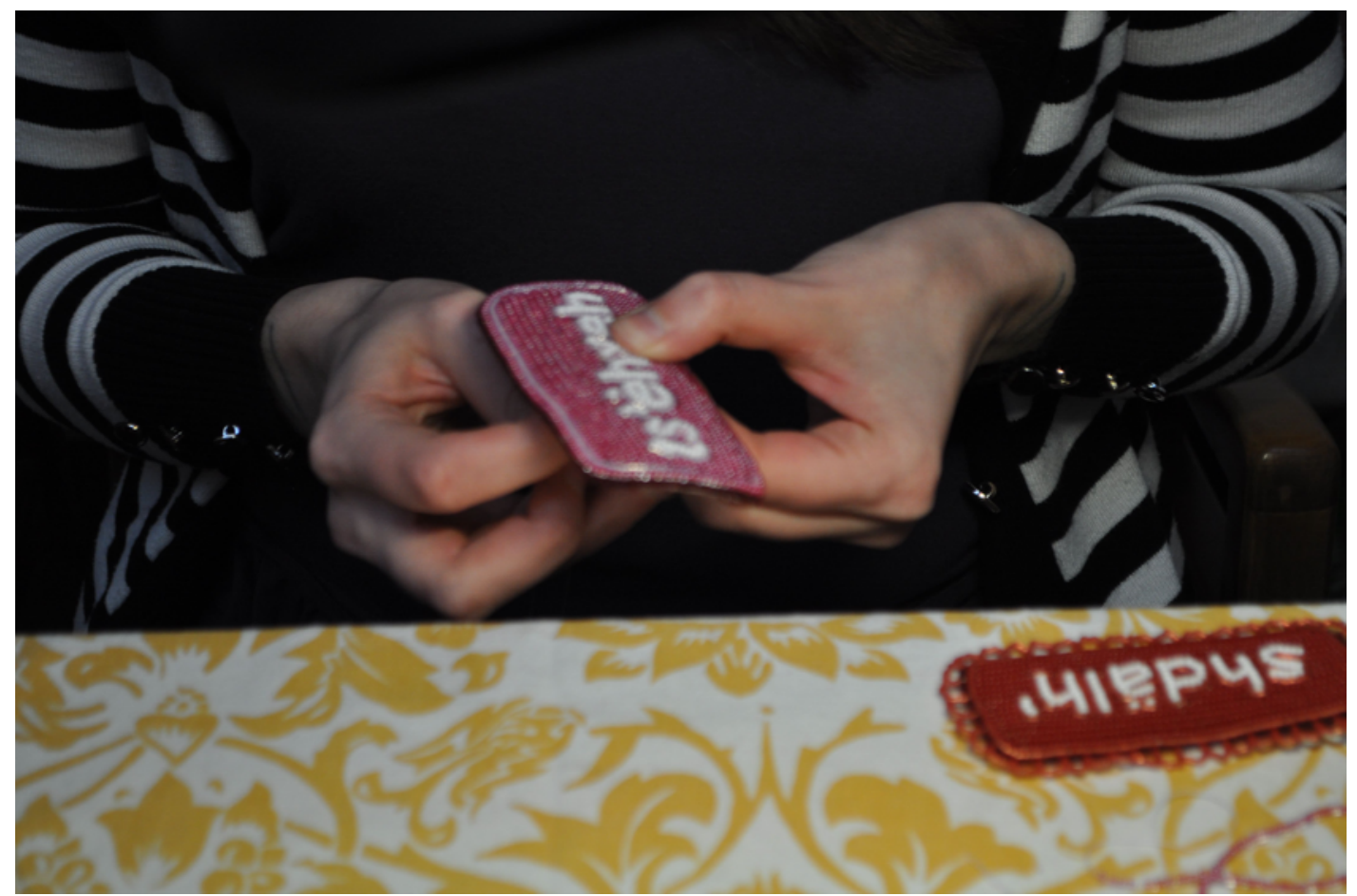

Notes: Photograph by Ingrid Percy.

\section{Class Workshops: Structured visits}

Findings suggested that within structured class visits, course content was exemplified through the stories told by the artist. Over the course of the month, Teresa Vander Meer-Chassé worked closely with several groups of students and faculty. Pre-service teachers in both elementary and secondary art education courses worked with Teresa to understand inquiry-based approaches to pedagogy and Indigenous ways of learning. Through this work they not only learned beadwork but examined and questioned how they teach and learn as they developed their own teaching approaches. Students taking Indigenous Education courses visited the gallery to engage with Teresa about how artistic pedagogies may enrich their understandings about Indigenous histories and education. Students in Math Education courses came to understand how artistic methods may allow for multi-modal ways of learning. A health recreation student who visited the gallery during one of her Art Education class claimed that the visit re-affirmed her understandings about multiple ways of learning, prompting her to consider how she learns in informal settings.

Art Educator Sheila Karrow scheduled class time to work with Teresa. She sent her students in groups of 10 to learn to bead with Teresa. Having been an artist-in-residence in classrooms, she recognized that any opportunity for students to learn from an artists' practice enriches student learning. That said, the large classes and lack of time for in depth engagement was a barrier for more in depth learning. Regarding this, she said: "I wish they had more class time 
to go work with her. There's that idealized vision of how we'd like it to play out and their realistic schedule with a course load that was maximized. The reality of that level involvement in beading didn't play out as we hoped but they still learned from it."

As the professor of an Indigenous Education course for elementary education undergraduate students, Carmen Rodriguez de France brought two classes to the space. When asked why she brought her students to the gallery, she said:

I think, as an educator, it is unfortunate that in many schools, art programs are an add on. Especially in elementary schools. I feel like art is a doorway we should all have access to even if we are not professional artists. We should offer these doorways to learners as a way of expressing themselves and express their learning, whatever that is ... math, science, biology, or whatever. It is too bad that schools see art as a subject matter rather than integral to their learning.

Carmen explained how Teresa brought an experienced example that reinforced many ideas discussed in class that allowed for a deeper connection for students. Through personal stories, students understood her world view:

The fact that Teresa Vander Meer-Chassé is from the Yukon; she has a particular world view and a particular way of being because of how she's connected to art and how she grew up and how she describes the process of learning to bead. And how when she came to university, she picked it up again, and she understood herself differently when she reconnected with art than she did when she was first exposed to art. Life experience gives us that space. So, for me, the hiatus that she described in her learning and her connection to how she picked it up again when she was in an urban space outside of her community, illustrates how she was looking for some kind of reconnection or finding herself in this particular space. She talks about walking in two worlds. With one of my groups that visited with her, I had just explored the topic of urban Aboriginal people and we came to the space and Teresa Vander Meer-Chassé offered all this information. She described and embodied many of these challenges that Indigenous families might have faced when moved outside of their own space.

Carmen spoke hopefully about how these small encounters may plant a seed for future understandings that take time to be understood. 


\section{Figure 13}

Teresa Vander Meer-Chassé performing a workshop with students in Wilfrid Johns Gallery, 2019.

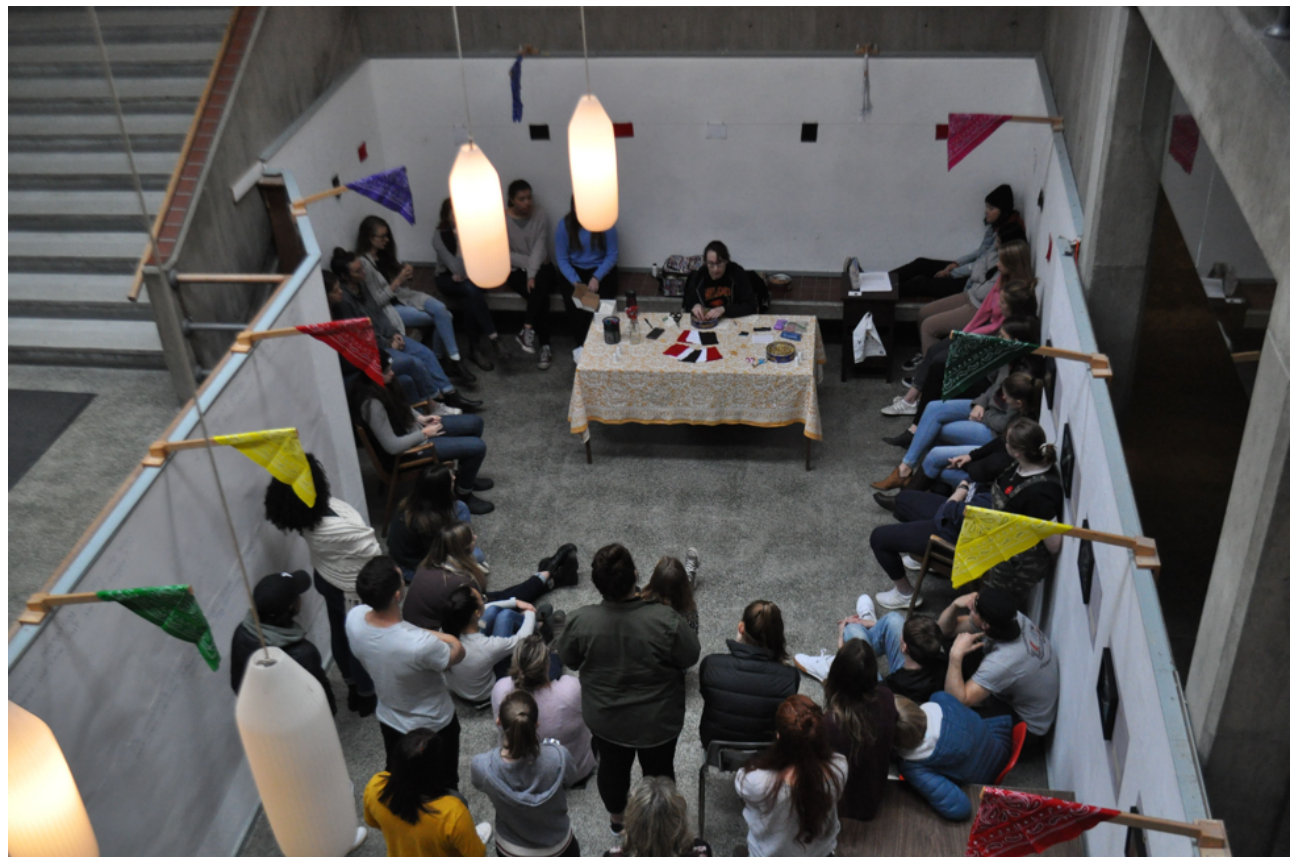

Notes: Photograph by Ingrid Percy.

\section{Artistic Inquiry in a Secondary Art education class: Unstructured time}

Through conversations with the professor (Regan Rasmussen) and observation of students, it was found that students preferred working with Teresa Vander Meer-Chassé in an unstructured way, where they could learn to bead and discuss ideas without the pressure of completing tasks or assignments. Prior to the residency, Secondary Art Education course instructor, Regan Rasmussen met with Teresa to discuss possibilities. Regan's teaching approach utilized inquiry with connections to the Core Competencies and Big Ideas from the BC arts curriculum. She appreciated the significance of having students work directly with an Indigenous artist to deepen their understandings of the First People's Principles of Learning, a key component of the curriculum. Adopting an inquiry-based approach to working with Teresa allowed for new understandings to unfold between the students and artist. Regan Rasmussen describes her intentions:

Together we determined that throughout the residency we could model aspects of inquirybased learning through art. Key to any inquiry-based process is posing questions about what you are curious about; what you want to find out more about. So, we viewed the residency as an opportunity to engage with Teresa Vander Meer-Chassé, her questions, students' questions, and the process of collaborative 'making.

Over the course of the month, Regan's students met during class time in the gallery with Teresa on two separate occasions. During this time, students could also visit the gallery on their own time to quietly bead or engage in conversations with Teresa and other students. Visual journal 
reflections documented thoughts, connections, and new questions arising from time spent in the gallery. Students were inspired by Teresa's watch-and-learn approach that didn't require templates or written instructions.

Regan indicated that involvement in the residency provoked students to also consider aspects of formative and summative assessment in learning. She said: "They came to question what should or should not be measured and assessed in learning. They came to appreciate that certain things cannot be marked and can't be assessed."

In particular, Regan commented on how providing space and time during a tightly scheduled program had a big impact on students. The theme of time came up in many discussions related to the BC curriculum Big Idea "Learning requires time, patience and perseverance." Schedules within schools often can't allow enough time or space for reflection. One student in her final inquiry project asked, "How can we find time for reflection and mindful breaks to deepen learning?"

\section{Figure 14}

Teresa Vander Meer-Chassé beading with students in Wilfrid Johns Gallery.

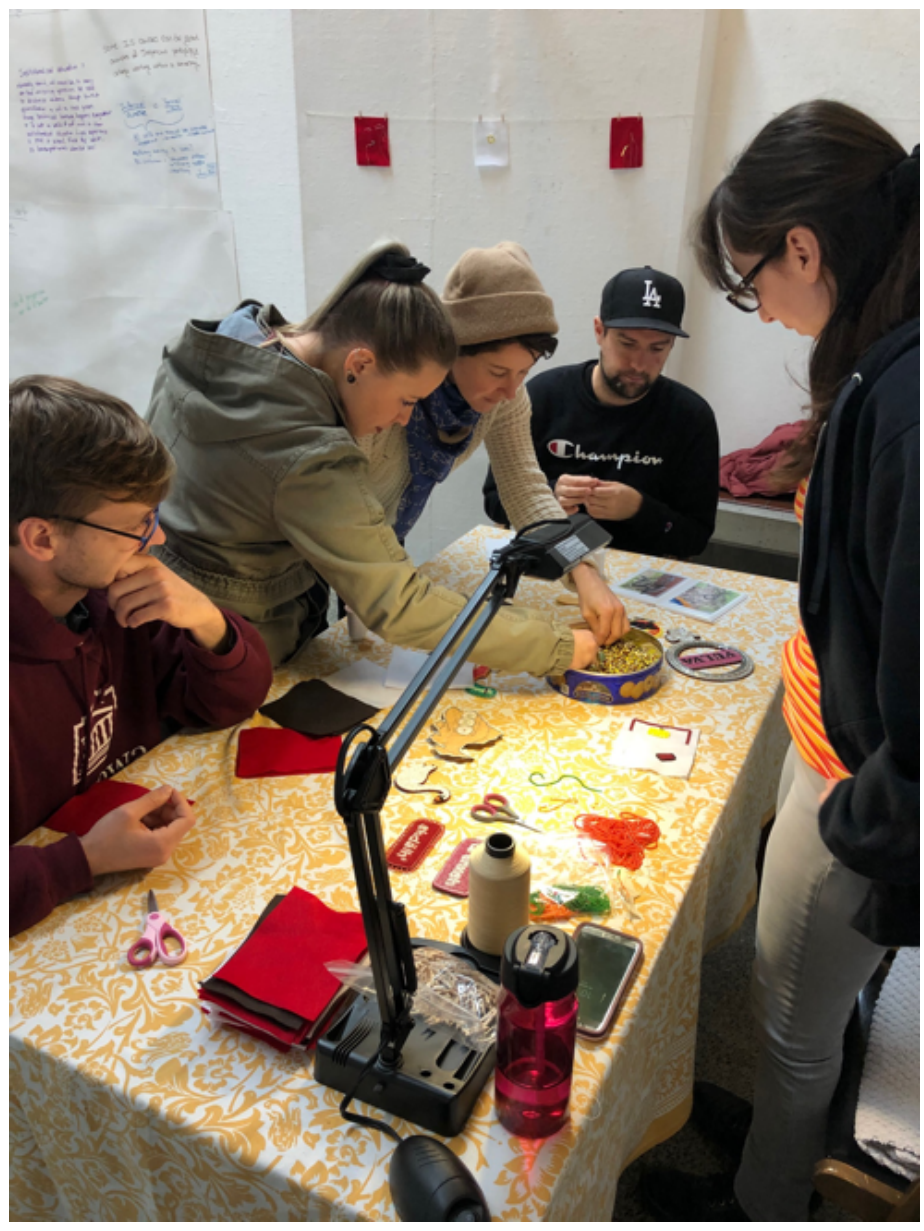

Notes: Photograph by Regan Rasmussen. 


\section{Figure 15}

Teresa Vander Meer-Chassé beading with students in the Wilfrid Johns Gallery.

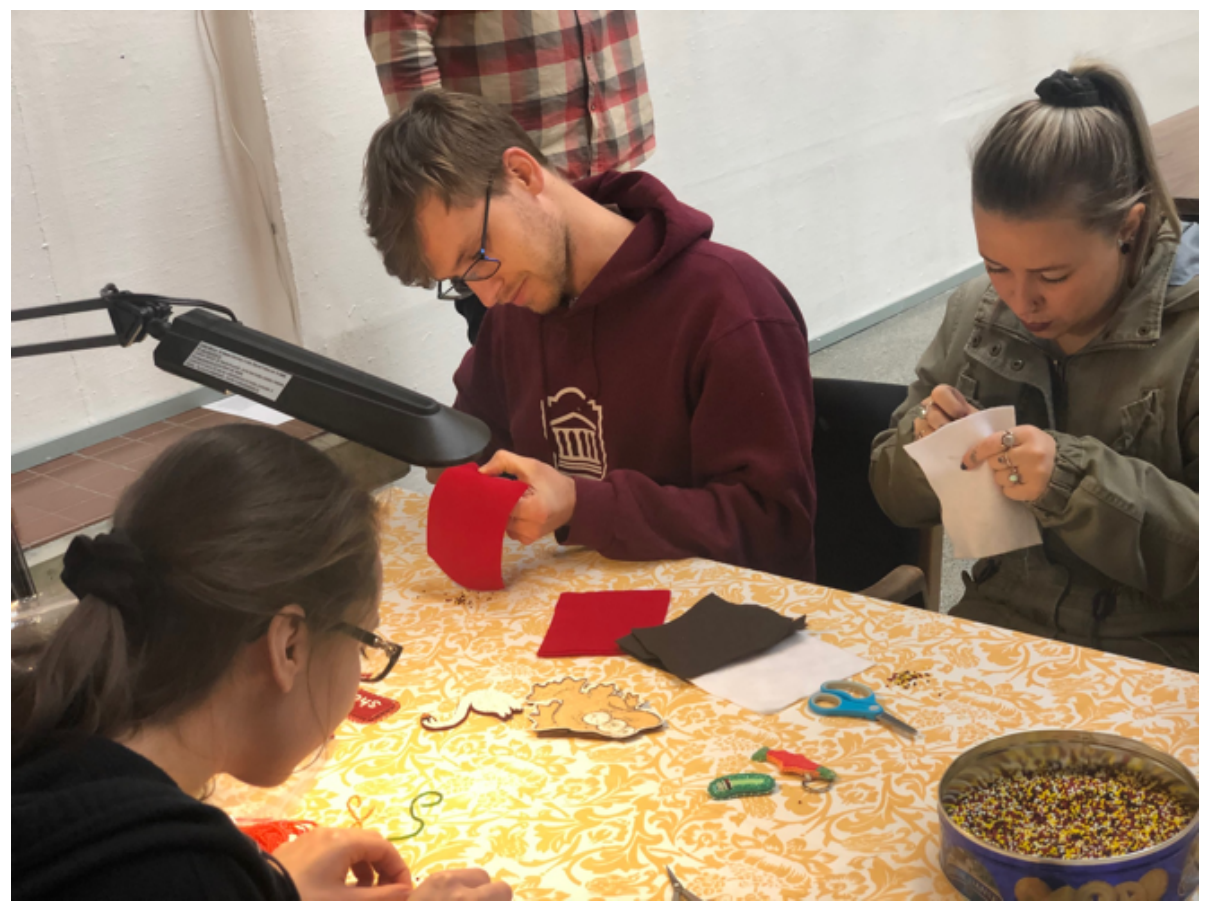

Notes: Photograph by Regan Rasmussen.

\section{Individual and small-group visits: Informal learning through conversation}

Through observations, discussions with the artist and follow up interviews, it was found that the space and time provided by the residency for one-on-on art-making or small groups yielded the deepest impact and revealed the potentials of an artist residency moving forward. In these cases, the learning was not simply in extending, reinforcing, exemplifying or enhancing course outcomes, but rather provided a pedagogical experience beyond their course content. These outcomes demonstrated the need to provide spaces for dialogue through making that bring together people from multiple backgrounds. Over the course of the month, students from across campus and in the community came to talk and bead with Teresa Vander Meer-Chassé. Art history students expressed that talking with Teresa not only deepened the content in their Indigenous Art History course, but allowed for an insightful conversation with a peer about her experiences beyond graduation. A woman who came to campus daily to care for her grandchild while her daughter took courses in the department, came across the residency and spent hours one day beading and talking with Teresa, thus revealing potentials for cross-generational encounters with visitors on campus. In addition to students from across the university visiting the gallery, Teresa engaged with local curators, community members and artists. She spent an afternoon beading with a local high school teacher and a group of secondary school students.

These unplanned connections were exemplified through one encounter between a faculty member, an undergraduate student and Teresa. We address this encounter through excerpts from an interview with Shauneen Pete, the Indigenous Resurgence Coordinator in the faculty and an 
undergraduate student in her $3^{\text {rd }}$ year of a Bachelor of Education specializing in Elementary Education.

Shauneen Pete brought in a perspective drawn from her life experience and academic work. She described her interest in going to the gallery:

I love kitchen table talk and I love reclaiming institutional spaces with kitchen table activities. I love kitchen table methodology in my own classrooms because I think it brings people together in a more unformal way and allows for a more natural interaction and dialogue that is really informed by relationality. So, for me it's really important pedagogically. I was in my office and realized I need a brain break so went down to sit with Teresa and a student and it was a wonderful experience. I was looking to distance myself from my headspace where I'm thinking about questions about decolonizing pedagogies and so I wanted to get back into myself and my own body.

Shauneen described how she entered the space while Teresa was beading and talking with another student. She explained how she gradually entered into this dialogue:

I picked a red piece of felt and drew my flower out with a pen. Then I was laughing because I couldn't thread my needle which took a long time, which reminded me that in learning experiences we enter into a space of humility and we allow that to teach us as things shift internally. So, I did feel this shift from the business of my mind more into my body and in that recognition of that switch, I threaded my needle. And in the meantime, I'm listening to the story of the student, and listened to Teresa's interaction. And then entering into that conversation recognizing that there was already a relationship established there and you don't really want to interrupt that. But there is a natural opening that happens where you are then in it and contributing to that conversation.

Natalie, a third-year undergraduate student was in the gallery when Shauneen came in. During her time with Teresa, Natalie spent four hours beading, while engaging in conversation. They talked at length about her experiences as a self-taught artist. She engaged in conversations about Indigenous pedagogies with Shauneen and Teresa. Throughout these conversations, she reflected on her experiences in high school growing up in northern BC with a large Indigenous student population, reading novels about residential schools. Through her conversation with Shauneen, she considered the impact of these books on students. Regarding this conversation, she said:

Listening to Teresa and Shauneen for an afternoon, I was thinking I need to keep doing this, reaching out, talking to people. Because the knowledge I have is specific to one area and what I experienced in school. So, I think it motivated me to keep a hold of not knowing everything.

Shauneen discussed another meaningful moment in this conversation:

There was a student sitting with us (Natalie)). I've been in her class a couple times. And this gave us a more intimate conversation because she was sharing a story about her family. She's from up north and she misses the cadence of speech, there is a rhythm to the way people in her community speak and she misses it. And I don't know if we took up that conversation naturally or if it triggered for us this memory of back home. My partner says I speak different with Indigenous people, so it was interesting hearing that bit reaffirmed at the table. We did some memory work and we started to share stories in that space and it helped us to see each other's humanity a bit more, as women, mothers and daughters. These conversations came up naturally and casually. So, we talked about how we can create these kinds of pedagogical moments in our own classrooms and our own teaching.

Regarding the space and the potentials of residencies, Shauneen expressed: 
So that part for me was another really important reminder of the need to create these spaces within the academy. It's healthy for us. And in so many places we are in a cube separated from each other not deepening that discussion, not deepening that relationship and we are rewarded for that isolation and so to come to the kitchen table was another experience and reminder that those relationships are essential, they're central to the work we need to do moving forward.

\section{Figure 16}

Teresa Vander Meer-Chassé beading with Faculty and Student in Wilfrid Johns Gallery.

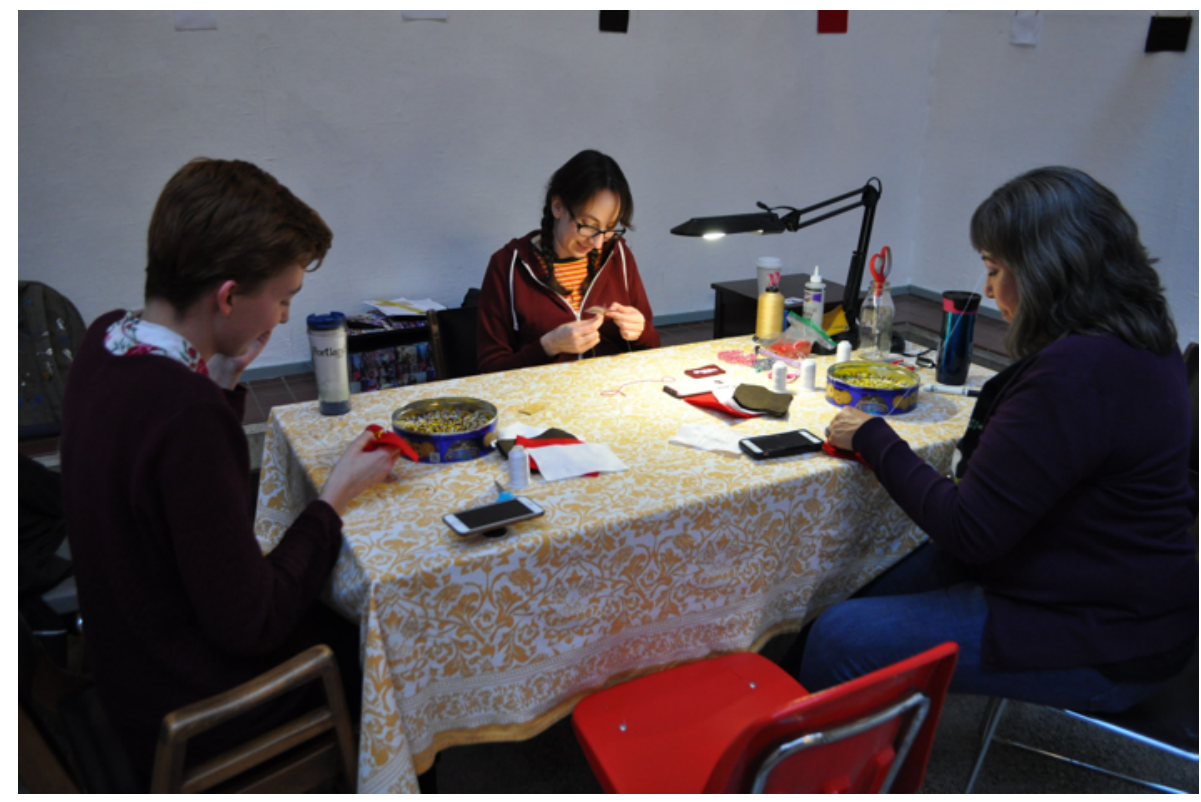

Notes: Photograph by Ingrid Percy.

\section{Reflections from Ingrid Percy: Emergent conversations}

I was pleased be invited to work as Alison's Research Assistant on this project. My enthusiasm arose from my ongoing work as a professional visual artist, art educator and arts advocate, in addition to my research as a doctoral student which is centred on community engagement, visual arts education, experiential learning, and the role of artists in post-secondary institutions in Canada. Currently an Associate Professor in Visual Arts at Memorial University, I have taught visual arts studio courses at the post-secondary level for over twenty years. I am interested in action-oriented research that is generative and illuminating - that opens up conversations and broadens understanding between individuals and communities with diverse geographical, cultural, political, philosophical perspectives and lived experiences.

I place great importance on activities that support artists in the production and sharing of their work. I value projects that support voices of marginalized individuals and communities such as Indigenous, queer, racialized and feminist perspectives. In the context of Canada's Truth and Reconciliation Commission, I believe that it behooves all of us to 
Indigenize academia or transform the academic area to be another kind of space, altogether.

Working on this project allowed me to further explore some of my epistemological underpinnings through direct engagement with Teresa Vander Meer-Chassé as well as through my observations of Teresa's interactions with individuals and groups during her residency. I appreciated that, from the outset, Alison framed the project as a collaborative endeavour and recognized that everyone who participated in the process would contribute a valuable perspective and help shape the outcomes. This is an approach that I have adopted more consciously in my own collaborations since working on this project.

I felt heartened that so many students, instructors, artists, educators, administrators, and philanthropists made the effort to come to the gallery and to sit and bead with Teresa and engage in important dialogue. Conversations pivoted from intimate and personal conversations about identity, race, politics, Indigenous and non-Indigenous relations to broader, more public dialogues about similar issues as well as pedagogy, teaching and learning, hands-on learning, etc. It was impossible (and perhaps undesirable) to document every conversation that occurred between Teresa Vander Meer-Chassé and her visitors but in the end, I do hope that the knowledge that was communicated each way has, and does, lead to policies and practices that are more empathic and responsive to non-western ways of knowledge. Ultimately, I think we all have a lot to learn from each other and this was one step in that process of opening up discourse to broader perspectives. This will make us all stronger.

\section{Figure 17}

Teresa Vander Meer-Chassé beading with students in Wilfrid Johns Gallery.

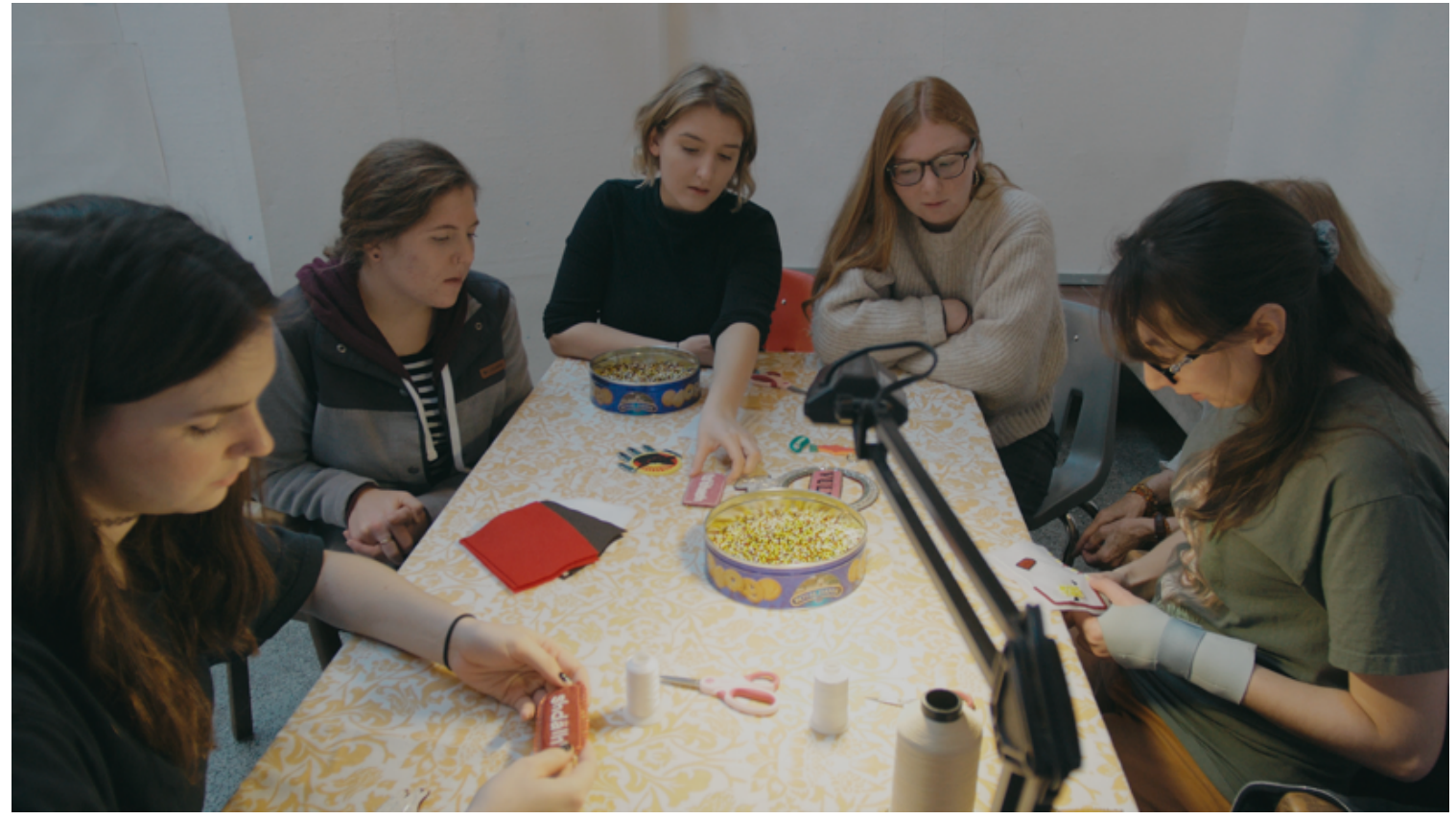

Notes: Photograph by Ben Pickering. 


\section{Creating Space for Spending Time}

This residency created space, created a mood and a feeling perhaps where time stands still a bit. (Shauneen Pete)

The themes of space and time were addressed by art educators, Indigenous educators and students during and following the residency. Through the residency, Teresa Vander Meer-Chassé sought to create a welcoming space for faculty and students to spend their time. As discussed through the interviews, the creation of the space prompted the artist and visitors to consider how they structure time within their own lives and those of their students. Time is framed within many of these conversations as something we are lacking, something we are seeking out or something that is structured. While some faculty and students regretted not having enough time to finish their beadwork with Teresa, other students discussed finding time to reflect or to be mindful through making within a highly structured program. Through this research, we contend that art making is a relational act, and that through creating spaces for art making, we are setting the stage for time and space to function differently through creating spaces for new relationships to emerge through making and conversation. These are the lenses through which we developed and engaged with this residency.

Through working with Teresa, students, art educators and Indigenous Educators throughout the month, we have come to more deeply understand how Indigenous pedagogies may similarly address ways that time and space are structured within an educational space. Further, we came to embrace ways that through occupying a space within an academic setting, an artist-inresidence may confront colonial ways of learning, and open up possibilities for artistic ways of knowing that embrace relationships and creative encounters. In an article entitled, Being 'Lazy' and Slowing down: Toward Decolonizing Time, our body and Pedagogy, Shahjahan (2015) argues for "reformulating the notion of 'time' and temporalities of academic life" (p. 488). Further, he argues that "in order to reconnect our minds to our bodies and center embodied pedagogy in the classroom, we should disrupt Eurocentric notions of time that colonize our academic lives" ( $p$. 488). Through the residency, while providing time and space for beading and conversation, Teresa simultaneously provoked visitors to consider the pedagogies that are reinforced within the structure of the university. Perhaps the most explicit example of this provocation was through a student response on the comment wall (by an unidentified visitor) that said: "Indigenous and Western pedagogy are not cohesive. However, for many reasons, our society needs to adapt and incorporate ways of viewing the world and living, but this will take deconstructing years of learned behaviour and worldview, which begins with education." The residency highlighted the challenges and barriers to such an endeavor, as students and faculty alike had difficulty finding time in their busy schedules to spend enough time in the gallery. On the other hand, the research revealed moments of hope and possibility for meaningful exchanges through conversation and artmaking, through creating time and space for art. 


\section{Figure 18}

Teresa Vander Meer-Chassé 's Installation in Wilfrid Johns Gallery.

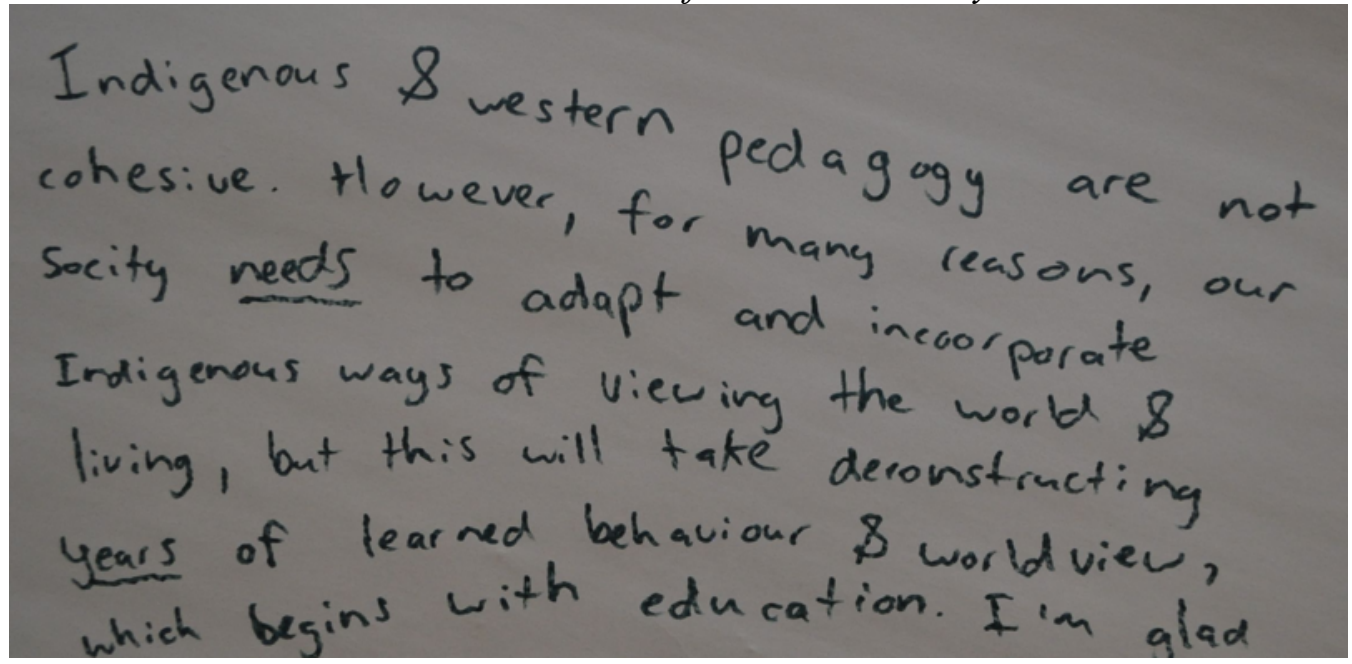

Notes: Photograph by Ingrid Percy.

\section{Figure 19}

Teresa Vander Meer-Chassé in Wilfrid Johns Gallery.

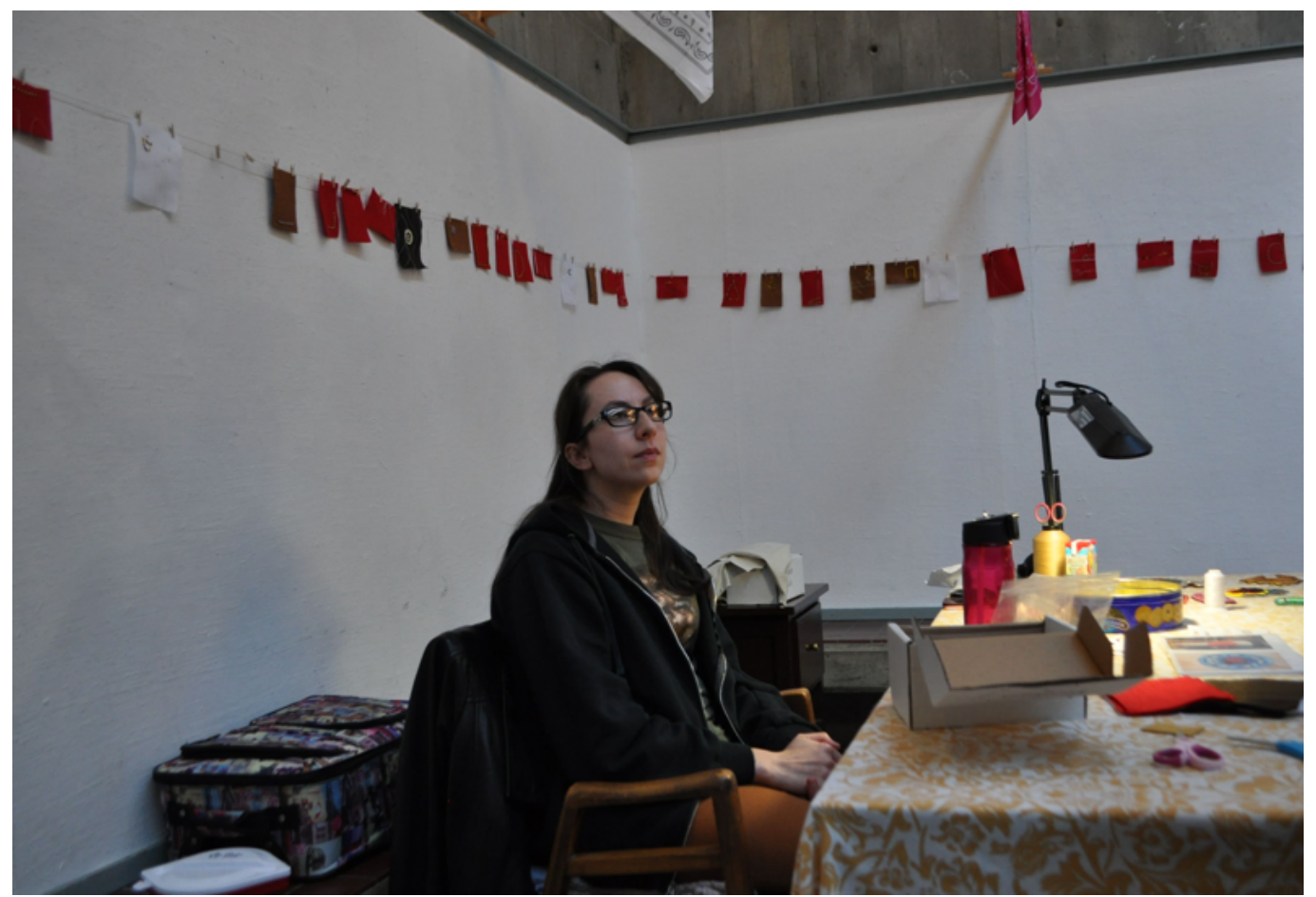

Notes: Photograph by Ingrid Percy. 


\section{Figure 20}

Teresa Vander Meer-Chassé 's Installation in Wilfrid Johns Gallery.

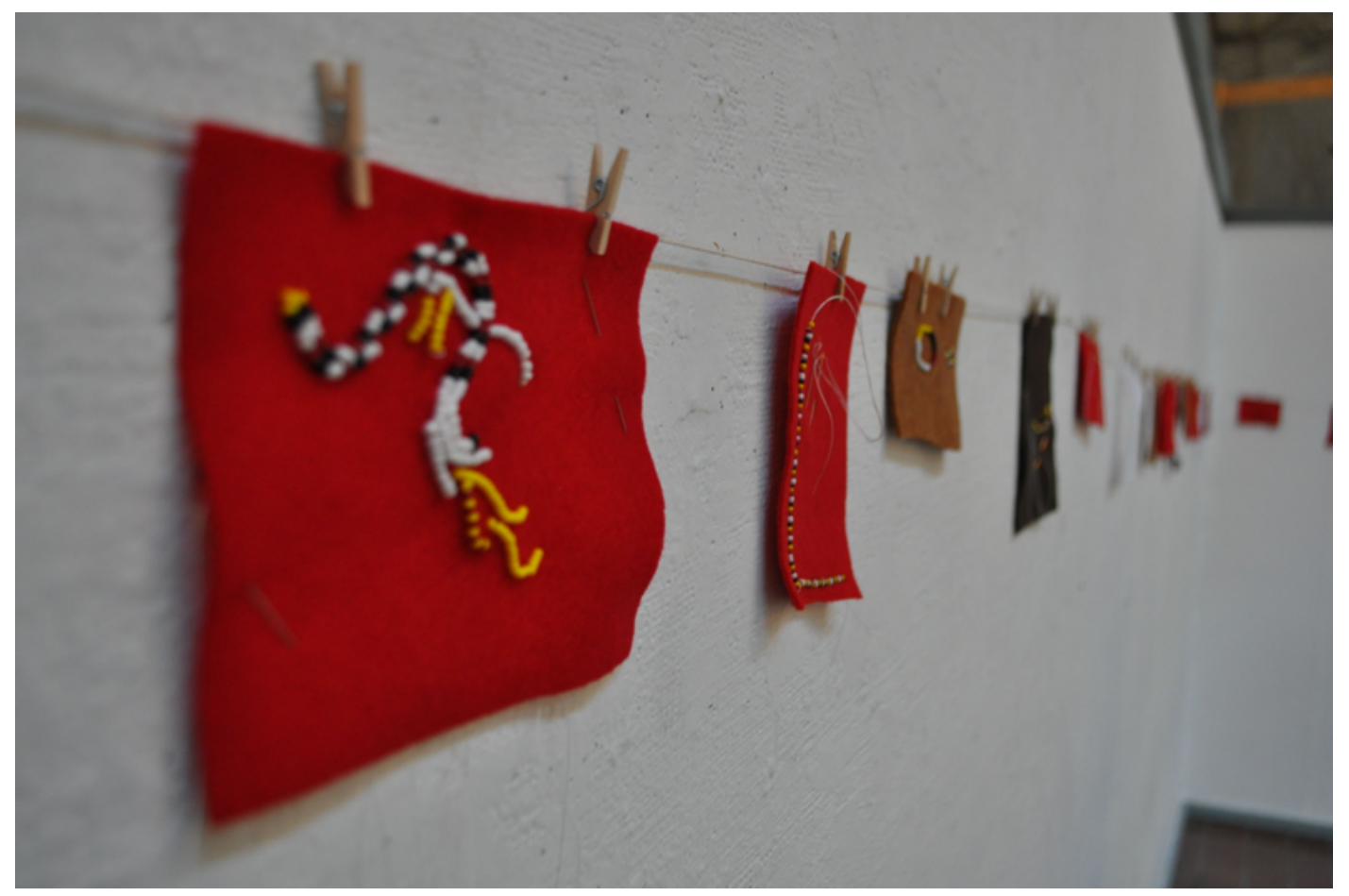

Notes: Photograph by Ingrid Percy.

\section{Conclusion}

Through examining the artist-in-residence program from multiple lenses, viewpoints and approaches, it is clear that the strength of the project arose out of its emergent structure. Rather than being developed as a pre-set plan to address prescribed learning outcomes for students, the residency highlighted the importance that it is generated by both the artistic and pedagogical concerns of the artist, even if they confront faculty and students to re-examine how they are learning and what they are learning. In this case, the inquiry-driven approach developed by Teresa Vander Meer-Chassé, through her lens as an Indigenous artist, challenged visitors to consider the structure of learning itself. Through inhabiting this space, she engaged in conversations with faculty and students about spaces of learning, particularly the value of unstructured time, informal learning and the conversations that emerge through providing space and time for this. This finding was supported by faculty, students and the artist who claimed that the richest learning experience was during informal moments when they spent time in small groups making and conversing with Teresa. Thus, through this residency, we propose that the value of an artist-in-residence is not through pre-planned learning outcomes that support a defined curriculum, but rather through the capacity of an artist-in-residence to prompt students and faculty to consider ways of learning that fall outside of how they understand curriculum. In this case pre-service teachers questioned their assumptions, expanded their understandings of what constitutes learning and re-considered how they will structure time and place to support learning. Because each artist enters a space with their own research-creation methodology, these results are specific to this residency. Therefore, the 
outcomes of the project reveal that additional research that includes multiple artists-in-residence would contribute to a more complicated and complex understanding of the relationships between artistic research and pedagogy and the ways that artists-in-residence may impact learning.

\section{References}

Adams, J. (2005). Room 13 and contemporary practices of artist-learners. Studies in Art Education, 47(1), 23-33.

Art Starts in Schools (2021, August 22). Art Starts. https://artstarts.com

Ash, N. (2016). Artist-in-residence: A project developed and carried out at the UdK Berlin between 2014 and 2016. In K. Winderlich (Ed.), Artist in residence (pp. 12-21). Universitat derKunste Berlin.

Barrett, E. \& Bolt, B. (Eds) (2007). Practice as research: Approaches to creative arts enquiry. I.B. Tauris.

Barrett, E., \& Bolt, B. (Eds.) (2013). Carnal knowledge: Towards a 'new materialism' through the arts. I.B. Tauris.

Bartlett, C., Marshall, M. \& Marshall. A. (2012). Two-Eyed seeing and other lessons learned within a co-learning journey of bringing together Indigenous and mainstream knowledges and ways of knowing. Journal of Environmental Studies and Sciences, 2(4), 331-340.

Battiste, M., \& James (Sa'ke'j) Youngblood Henderson. (2009). Naturalizing Indigenous knowledge in Eurocentric education. Canadian Journal of Native Education, 32(1), 5.

Battiste, M., Bell, L., \& Findlay, L. M. (2002). Decolonizing education in Canadian universities: An interdisciplinary, international, Indigenous research project. Canadian Journal of Native Education, 26(2), 82-95.

Province of British Columbia. (2021, August 22). BC's Curriculum. https://curriculum.gov.bc.ca

Bolt, B. (2016). Artistic research: A performative paradigm? Parse Journal, 3, 129-142.

Bonneau, V. (2019). Creativity abuzz at McGill Art Hive: A unique space in the Faculty of Education provides the entire McGill community an opportunity to engage in visual art. https://giving.mcgill.ca/all-stories/creativity-abuzz-mcgill-art-hive

Emily Carr University of Art and Design. Artist in Residence Programs. (2021, August 22)

Emily Carr University of Art and Design Artist in Residence Programs.

https://www.ecuad.ca/academics/specialty-programs/artist-in-residence-programs 
Gaudry, A., \& Lorenz, D. (2018). Indigenization as inclusion, reconciliation, and decolonization: Navigating the different visions for indigenizing the Canadian academy. AlterNative: An International Journal of Indigenous Peoples, 14(3), 218-227.

Gubrium, J. \& Holstein, J. (Eds.) (2003). Postmodern interviewing. Sage Publications.

Hunter, M. A., Baker, W., \& Nailon, D. (2014). Generating cultural capital? Impacts of artistsin-residence on teacher professional learning. Australian Journal of Teacher Education, 39(6), $74-88$.

Hunter-Doniger, T. (2015). An artist-in-residence: Teaching with a sense of urgency. International Journal of Education through Art, 11(2), 229-243.

Hunter-Doniger, T., \& Berlinsky, R. (2017). The power of the arts: Evaluating a community artist-in-residence program through the lens of studio thinking. Arts Education Policy Review, $118(1), 19-26$.

Lachapelle, R. (2016). The Ottawa Roman Catholic Separate School board's artists-in-residence program (1970-1988): One point of view. Canadian Review of Art Education: Research and Issues / Revue Canadienne de Recherches et Enjeux en Éducation Artistique, 42(2), 3. https://doi.org/10.26443/crae.v42i2.5

LeBlanc, N., \& Irwin, R. L. (2019). A cosmopolitan imagination: Reimagining national identity through art. SynnyT/Origins: Finnish Studies in Art Education, 2, 344-359

Loveless, N. S. (2019). How to make art at the end of the world: A manifesto for researchcreation. Duke University Press.

McGill Univerisity. (2021, August 22) McGill Art Hive. https://www.mcgill.ca/arthive/

Miles, J., \& Springgay. S. (2020). The indeterminate influence of Fluxus on contemporary curriculum and pedagogy. International Journal of Qualitative Studies in Education, 33(10), 1007-1021 .

Mount Allison University. (2021, August 22). Pierre Lassonde Artist-in-Residence Program. https:/www.mta.ca/Community/Academics/Faculty_of_Arts/Music/Bragg_Opportunities/Bragg _Artist-in-Residence/Bragg_Artist-in-Residence/

Pidgeon, M. (2014). Moving beyond good intentions: Indigenizing higher education in British Columbia universities through institutional responsibility and accountability. Journal of American Indian Education, 53(2), 7-28.

Pink, S. (Ed.) (2012). Advances in visual methodology. Sage Publications.

Queen's University. (2021, August 22). Koerner Artist-in-Residence Program. https://www.queensu.ca/bfa/about/koerner-artist-residence-program 
Quest University. (2021,August 22). Artist-in-Residence. https://questu.ca/artist-in-residence/

Ragoonaden, K., \& Mueller, L. (2017). Culturally responsive pedagogy: Indigenizing curriculum. Canadian Journal of Higher Education, 47, 222-246.

Rose, G. (2010). Visual methodologies. Sage Publications.

Rotas, N. \& Springgay, S. (2014). How do you make a classroom operate like a work of art? Deleuze-guattarian methodologies of research-creation. International Journal of Qualitative Studies in Education, 28(5), 552-572.

Shahjahan, R. A. (2015). Being 'lazy' and slowing down: Toward decolonizing time, our body, and pedagogy. Educational Philosophy and Theory, 47(5), 488-501.

Springgay, S., \& Truman, S. (2016). Propositions for walking research. In K. Powell, P. Burnard \& L. Mackinlay (Eds.), Routledge Handbook of Intercultural Arts (pp. 259-267). Routledge.

Styhre, A., \& Eriksson, M. (2008). Bring in the arts and get the creativity for free: A study of the artists in residence project. Creativity and Innovation Management, 17(1), 47-57.

Tanaka, M., Williams, L., Benoit, Y. J., Duggan, R. K., Moir, L., \& Scarrow, J. C. (2007). Transforming pedagogies: Pre-service reflections on learning and teaching in an indigenous world. Teacher Development, 11(1), 99-109.

Ungemah, L. D., \& Stokas, A. G. (2017). Making space for the possible: Artists-in-residence in community college. Art Education, 71(1), 24-31.

University of Victoria. (2021, August 22). University of Victoria. https://www.uvic.ca

University of Victoria. (2021, August 22). Artist in Residence.

https://www.uvic.ca/research/centres/csrs/fellowships-awards/apply/artist/index.php

Weber, S. (2008). Visual images in research. In J. G. Knowles \& A.L. Cole (Eds.), Handbook of the arts in qualitative research: Perspectives, methodologies, examples, and issues (pp. 41-54).

Sage Publications.

Winderlich, K. (Ed.) (2016). Artist in residence. Universitat der Kunste Berlin.

Woywod, C., \& Deal, R. (2016). Art that makes communities strong: Transformative partnerships with community artists in K-12 settings. Art Education, 69(2), 43-51.

Zaliwska, Z., \& Springgay, S. (2015). Diagrams and cuts: A materialist approach to researchcreation. Cultural Studies - Critical Methodologies, 15(2), 136-144. 